\title{
Home-Biased Analysts in Emerging Markets
}

\author{
Sandy Lai and Melvyn Teo*
}

\begin{abstract}
We find that local analyst recommendations are systematically more optimistic than foreign analyst recommendations in emerging markets. The effects of this novel "home bias" among local analysts overwhelm any information asymmetry between foreign and local analysts. Consequently, local analyst upgrades underperform foreign analyst upgrades, while local analyst downgrades outperform foreign analyst downgrades. Neither foreign investors, local institutions, nor retail investors appear to be fully cognizant of this bias. Trade reactions suggest that foreign investors overestimate the bias in foreign analyst recommendations while local institutions underestimate the bias in local analyst recommendations. These results are pervasive across countries, time periods, and stock groupings, and can be traced to investment banking pressure.
\end{abstract}

\section{Introduction}

The financial press in developed markets is rife with reports of conflicts of interests among sell-side analysts. For example, "Did Wall Street Really Learn Its Lesson?" which appeared in The New York Times on April 9, 2006, challenges the view that the high profile investigations in 2001 led by New York State Attorney General Eliot Spitzer have curtailed the tendency of sell-side analysts to issue optimistic recommendation reports. Yet, in emerging markets, such as Asia, one finds scant anecdotal evidence of analyst conflicts of interests. A search of the global database Factiva over 2005 and 2006 yields only one $\operatorname{article}^{1}$ on the recommendation bias of analysts in the region. Therefore, there seems to be less focus on conflicts of interests among analysts in emerging markets. Yet, the underlying drivers behind analyst optimism, such as investment banking pressure, ${ }^{2}$ may be

\footnotetext{
*Lai, sandylai@smu.edu.sg, and Teo, melvynteo@smu.edu.sg, Lee Kong Chian School of Business, Singapore Management University, 50 Stamford Road, \#04-01, S(178899), Singapore. We thank Kee-Hong Bae, Hendrik Bessembinder (the editor), Kalok Chan, Charles Chang, Cheol Eun, Roger Loh, David Ng, Steven Orpurt, Mark Seasholes, and especially Reuven Lehavy (the referee) for many helpful comments and suggestions. Charlene Su and Fiona Sy provided excellent research assistance. Editorial assistance was provided by Tracy Petersen. We are also indebted to Jae-Won Yang from the Korea Stock Exchange for generously supplying Korean IPO underwriter data.

${ }^{1}$ The search was based on the keyword phrase "asia and analysts and investment banking and bias." The article, "Analyzing the Analysts-Brokerages Get Screened," from The Business Times Singapore on January 4, 2005, noted that there was "an institutional bias towards buy recommendations."

${ }^{2}$ The agency issue here is that because sell-side analysts work for investment banks and brokerage houses, they may feel pressured to generate optimistic recommendations to support their firms' efforts in securing the next equity issue (see Michaely and Womack (2005) for further discussion).
} 
stronger with local analysts than with foreign analysts in these markets. For example, articles such as "Funds Raised by Taiwan's Firms via Banks," which appeared in Taiwan Economic News on July 6, 2006, and "DBS Still Tops in Capital Markets Here," from The Business Times Singapore on January 9, 2006, suggest that local underwriters dominate in the region. Hence, the analysts working for these local underwriters may be even more optimistic than their foreign counterparts.

This paper sheds light on the recommendation biases of local and foreign analysts on emerging market stocks. Using data from eight emerging Asian countries $^{3}$ between 1994 and 2003, we find that domestic equity issues in emerging Asian markets are dominated by local underwriters. In every country, at least $78 \%$ (by number) and 69\% (by market capitalization) of the equity issues are managed by local underwriters. To the extent that this is symptomatic of cultural and language barriers facing foreign underwriters or of the less lucrative nature of underwriting in emerging countries, it suggests that local analysts face much stronger investment banking pressures than do foreign analysts in these markets. We then test for systematic differences in recommendation optimism between local and foreign analysts. If, as argued by Michaely and Womack (1999) and others, investment banking pressures are responsible for sell-side analyst recommendation optimism, then we should observe greater optimism among local analysts. We find that the difference in optimism between local and foreign analyst recommendations is positive and statistically significant $(t$-statistic $=14.00)$. In addition, it is robust across countries and time periods, and pervasive across small, large, value, growth, index, and non-index stocks.

Next, we compare the post-announcement returns of local versus foreign analyst recommendations. If investment banking pressure is the main driver behind differences in local and foreign analyst recommendations, then we should observe that local upgrades underperform foreign upgrades while local downgrades outperform foreign downgrades. On the other hand, if foreigners are the smarter players in emerging markets, as advanced in Seasholes (2006) and Richards (2005), foreign analyst upgrades and downgrades should outperform local analyst upgrades and downgrades. Conversely, the reverse should prevail if local informational advantages dominate in emerging markets (Dvorak (2005) and Choe, Kho, and Stulz (2005)). We find that the difference in recommendation optimism translates to differences in announcement day returns. Foreign analyst buy recommendations reliably outperform local analyst buy recommendations by 24 basis points $(t$-statistic $=3.82)$ on the announcement day. Conversely, local analyst sell recommendations reliably outperform foreign analyst sell recommendations by -22 basis points $(t$-statistic $=-2.18)$ on the announcement day. Similar results are obtained with upgrades and downgrades.

To examine long-term recommendation performance, we adopt a calendar time portfolio approach and show that after controlling for return covariation with Fama and French's (1993) three factors, local analyst upgrades underperform foreign analyst upgrades by 3 basis points per day or $7.2 \%$ annualized, while local analyst downgrades outperform foreign analyst downgrades by -5.9 basis points per day or $-14.2 \%$ annualized. These results echo those of Barber, Lehavy, and

\footnotetext{
${ }^{3}$ These countries include India, Indonesia, Korea, Malaysia, Philippines, Singapore, Taiwan, and Thailand.
} 
Trueman (2007) who find that analysts facing greater investment banking pressure, i.e., those working for investment banks, generate upgrades (downgrades) that are less (more) informative than analysts facing less investment banking pressure, i.e., those working for independent research firms. The results also indicate that the recommendation performance differences that we observe cannot be simply traced to smarter foreign analysts or to a local informational advantage.

To further investigate the link between investment banking pressure and the difference in recommendation optimism between local and foreign analysts, we test whether in controlling for underwriter affiliation, the optimism difference is increasing in the aggregate investment banking deal flow and in the proportion of that flow directed toward underwriters from the country where the analyst is based. We find that local analysts are even more optimistic than foreign analysts when the local equity issue market is hot or when many investment banking deals are managed by local underwriters. Variation in these country-specific investment banking proxies can completely explain away optimism differences between local and foreign analysts. In contrast, other explanations, including the view that local analysts are under greater pressure to generate commissions (Jackson (2005)), that foreign analysts cover stocks with greater institutional presence that in turn serves as a disciplining device (Ljungqvist, Marston, Starks, Wei, and Yan (2007)), that foreign analysts have better reputations to safeguard (Stickel (1992)), that foreign analysts shade their recommendations to account for currency and country risk, that familiarity bias breeds greater optimism among locals (Bailey, Kumar, and $\mathrm{Ng}$ (2006)), and that local analysts suffer from the selection (McNichols and O'Brien (1997)) and cognitive biases (Kahneman and Lovallo (1993)) induced by underwriter affiliation, do not account for the bulk of the optimism differences. ${ }^{4}$

To gauge the ability of investors to unravel the recommendation optimism of local and foreign analysts, we evaluate the trade reaction of local retail investors, local institutions, and foreign investors to analyst recommendation announcements. Given our announcement day return results, if investors recognize the full extent of the bias in analyst recommendations, they should sell more following local analyst sells/downgrades than they buy following local analyst buys/upgrades. Conversely, they should buy more following foreign analyst buys/upgrades than they sell following foreign analyst sells/downgrades. Moreover, they should buy more after foreign analyst buys than after local analyst buys, and sell more after local analyst sells than after foreign analyst sells.

Using daily trade data from the Korea Stock Exchange, we find that while foreign investors and local institutions aggressively trade in the correct direction following analyst recommendation announcements, they do not fully appreciate the difference in optimism between local and foreign analysts. Foreign investors trade incorrectly as if foreign analyst sells/downgrades are more informative than foreign analyst buys/upgrades. In response to foreign analyst sells, foreign investors sell 2.23 times as much as they buy following foreign analyst buys. They also sell more following a foreign sell than following a local sell, despite the fact that the latter conveys more negative information. Local institutions trade incor-

\footnotetext{
${ }^{4}$ For instance, analysts from the Institutional Investor All-Asia teams are more optimistic than other analysts, which is inconsistent with the reputation story in which the better reputation of foreign analysts drives the lower levels of optimism among foreign analysts.
} 
rectly as if local analyst buys are more informative than local analyst sells. In response to local analyst buys, local institutions buy 1.48 times as much as they sell following local analyst sells. They also buy more following a local buy than following a foreign buy. In short, foreign investors overestimate the bias in foreign analyst recommendations while local institutions underestimate the bias in local analyst recommendations. Our trade reaction results, which are based on Korean daily trade data, challenge the Morgan Stanley view (The Wall Street Journal, July 14, 1992) that sophisticated investors are able to unravel and correctly assess the investment banking pressures of sell-side analysts, and dovetail with the view that investors do not fully recognize the bias in analyst research and are systematically misled by analyst reports.

This paper contributes to the literature by documenting optimism differences between local and foreign analysts in emerging markets and linking those differences to investment banking pressure. While there is a nascent body of work on international analysts, these studies mainly test for accuracy differences between local and foreign analyst forecasts and recommendations (see Orpurt (2006), Bae, Stulz, and Tan (2006), Bacmann and Bolliger (2006), and Chang (2006)). None of these papers focuses on the optimism differences between local and foreign recommendations or on the drivers of those differences. Unlike these papers, ours uncovers a "home bias" tions among local analysts than among foreign analysts. This study also shows that agency issues related to analysts' incentives to attract underwriting business are an important phenomenon in Asian as well as in U.S. markets.

The remainder of this paper is organized as follows. Section II provides a description of the related literature and data. Section III reports the empirical findings while Section IV discusses the results in light of several competing explanations. Section V concludes.

\section{Methodology}

\section{A. Related Literature}

The link between investment banking and analyst recommendation optimism is reasonably well established in developed markets. For example, Lin and McNichols (1998) report that lead underwriter U.S. analysts issue more favorable recommendations than unaffiliated U.S. analysts. Moreover, the three-day returns of the hold recommendations issued by the former are significantly more negative than those issued by the latter. Along the same lines, Michaely and Womack (1999) report that in the U.S. initial public offerings (IPOs) for which underwriter analysts issue buy recommendations underperform IPOs with buy recommendations from only unaffiliated analysts. This supports the view that underwriters attempt to boost the stock prices of the firms they have taken public. Similarly, Barber, Lehavy, and Trueman (2007) find that upgrades from U.S. investment banks underperform upgrades from independent U.S. research firms, while the

\footnotetext{
${ }^{5}$ This "home bias" is reminiscent of but distinct from the traditional home bias, i.e., the preference displayed by international investors for local stocks documented by French and Poterba (1991), Cooper and Kaplanis (1994), and Tesar and Wermer (1995).
} 
reverse is true for downgrades. They ascribe their results to the greater investment banking pressures facing investment banks.

Investment banking relations notwithstanding, other factors may also influence analyst optimism. Jackson (2005), using data from Australia, argues that the pressure to generate brokerage commissions can induce optimism among sellside analysts. Ljungqvist et al. (2007) contend that the presence of institutional investors moderates conflicts of interest in sell-side research and show that U.S. analysts issue less optimistic recommendations for U.S. stocks with high institutional ownership. Stickel (1992) finds that reputable Institutional Investor AllAmerican analysts deliver more accurate forecasts than other analysts. Hence, reputable analysts may eschew optimism for greater accuracy. Finally, affiliated analysts may be more biased simply because firms select underwriters who are more optimistic (McNichols and O'Brien (1997)) or because affiliated analysts genuinely believe that the firms their banks underwrite are superior to firms underwritten by competing banks (Kahneman and Lovallo (1993)).

In contrast to the large literature on analyst conflicts of interests in developed markets, little is known about such conflicts of interest in emerging markets. Most papers on international analysts focus instead on explaining the international home bias puzzle or the strong preference for local stocks among international investors (French and Poterba (1991), Cooper and Kaplanis (1994), and Tesar and Werner (1995)). One possibility for the home bias is that a local informational advantage exists. However, the extant literature on international investors offers mixed evidence. For instance, Dvorak (2005), Choe, Kho, and Stulz (2005), and Hau (2001) report that local investors outperform foreign investors in Indonesia, Korea, and Germany, respectively. Yet, Seasholes (2006), Froot, O'Connell, and Seasholes (2001), and Richards (2005) show that foreign investors outperform, especially in emerging markets.

Adding to this debate, studies on international analysts mainly test for accuracy differences between local and foreign analyst earnings forecasts. Orpurt (2006) finds that local analysts issue more accurate earnings forecasts than other analysts in Europe. Consistent with this, Bae, Stulz, and Tan (2006) demonstrate in their sample of 32 countries that local analysts issue superior earnings forecasts, especially in emerging countries where there is less informational disclosure. Conversely, Bacmann and Bolliger (2006) show that foreign analyst forecasts outperform local analyst forecasts in Latin American countries. Taking the middle ground, Chang (2006) reports that in Taiwan, foreign analysts with local presence issue recommendations that outperform those issued by local and other foreign analysts. None of these papers, however, contributes to our understanding of the conflicts of interest issues facing analysts in emerging countries.

\section{B. Data}

We cull analyst recommendations data from the Institutional Brokers Estimate System (IBES) Detail and Summary Recommendations file. Our sample covers eight emerging Asian countries-India, Indonesia, Korea, Malaysia, Philippines, Singapore, Taiwan, and Thailand - and extends from January 1994 to December 2003. Our choice of eight emerging Asian markets reflects the belief 
that emerging Asian markets are on average larger than emerging Latin American or East European markets, and they offer a longer time series and wider cross section of local and foreign analyst recommendations with which to maximize the power of the tests. Recent studies that focus on emerging Asian countries include Dvorak (2005), Choe, Kho, and Stulz (2005), Barber, Lee, Liu, and Odean (2006), and Richards (2005).

In IBES, the Detail Recommendations file provides a data entry for each recommendation announcement by each sell-side analyst whose brokerage firm contributes to the database. IBES parlays the original text recommendations to its own five-point rating system, i.e., 1 (strong buy), 2 (buy), 3 (hold), 4 (underperform), and 5 (sell). Unlike in the U.S., where the five-point rating scheme is widely used, the three-point rating scheme is popular among analysts in international markets. Many international analysts rate firms with a buy, hold, or sell recommendation. In such cases, IBES maps them to 1,3, and 5, respectively, in their five-point rating system. Hence, considerably fewer buy and underperform recommendations are found in our sample compared to the U.S. sample. ${ }^{6}$ To make the comparison of recommendations meaningful across analysts, we aggregate IBES ratings 1 and 2 as buy, and 4 and 5 as sell throughout the study. Also, to facilitate the interpretation of our results, we assign the values 1,2 , and 3 to sell, hold, and buy recommendations, respectively. ${ }^{7}$

The IBES Summary file provides a monthly summary for each firm covered in the database, with the number of outstanding ratings and the mean and the median of those ratings available on a monthly basis. We measure recommendation optimism as the difference between an analyst's recommendation and the current month's median consensus for the firm. The results using the mean consensus are virtually identical. Our regression analysis on recommendation optimism excludes recommendations with consensus levels generated from less than three recommendations. We do so because consensus levels generated from few recommendations are noisy and may not be representative of consensus belief among analysts. We classify each brokerage firm as either local or foreign depending on the location of the firm's headquarters. For each stock traded in country $x$, a brokerage firm is classified as local if it is headquartered in country $x$. It is classified as foreign otherwise. We obtain the headquarter information for each brokerage firm by hand from stock exchanges, securities and exchange commissions, and company Web sites. ${ }^{8}$

\footnotetext{
${ }^{6}$ Of the analyst recommendations in our eight-country universe, the proportion of strong buys, buys, holds, underperforms, and sells are $32 \%, 14 \%, 31 \%, 7 \%$, and $16 \%$, respectively. In the U.S., however, the corresponding proportions are $27 \%, 34 \%, 34 \%, 3 \%$, and $2 \%$, respectively, during the sample period. Clearly, there is a dearth of buys and underperforms in the IBES emerging market stock universe.

${ }^{7}$ Our results are robust to using the five-point rating system in place of the three-point rating system.

${ }^{8}$ The Jakarta Stock Exchange, Philippine Stock Exchange, and Singapore Monetary Authority provide a comprehensive list of brokerage firms that conduct business in the respective countries, including business and address information. In addition, we use information on the exchange member lists obtained from other stock exchanges and information on company Web sites to distinguish local from foreign brokerages.
} 
We employ daily return data from Datastream to examine the returns from following local and foreign analyst recommendations. ${ }^{9}$ We adjust for market returns using the daily Datastream total market indices for each country. Further, we match firms in IBES with those in Datastream using the IBES ticker symbol. Datastream only maintains a list of IBES ticker symbols for firms that are currently covered by IBES. For those firms in Datastream that are no longer covered by IBES, we manually match those using company names. We are able to match $91 \%$ of the firms in our IBES universe. The unmatched firms account for roughly $5 \%$ of the recommendations in our sample. Excluding them, we are left with 139,504 recommendations.

Table 1 presents summary statistics from our analyst recommendations data. Panel A reports the statistics for local and foreign analyst groups by country over the entire sample period. Panel B reports the statistics by subperiod. A few points are noteworthy. First, the eight emerging Asian markets have garnered substantial interest from foreign analysts. There are 74 foreign brokerages over the entire sample period, which is about two-thirds of the number of local brokerages. However, the ratio of the number of local to foreign brokerages has increased over the sample period, reflecting the expansion of the local brokerage industry in these countries. Second, foreign brokerages cover more firms than local brokerages in the early years, but the trend has reversed in recent years. On average, the firms covered by foreign brokerages are smaller than those covered by locals in the early years but are larger in recent years. Third, foreign brokerages are substantially larger than local brokerages. The number of analysts working for foreign brokerages worldwide typically exceeds 100 , while that for local brokerages is typically fewer than 30. Fourth, foreign brokerages are responsible for the bulk of the analyst recommendations in this region, but the proportion of the recommendations issued by local analysts has increased over the sample period.

To control for underwriter affiliation in our tests, we also use Securities Data Corporation's (SDC) equity issue data, which include managing underwriter(s), value of shares issued, issue price, and date of listing information, to generate country-specific investment banking proxies and to determine underwriter affiliation. In addition, we supplement the SDC data with IPO data from the Korean Stock Exchange, KOSDAQ, the Singapore Stock Exchange, the Philippine Stock Exchange, and Bursa Malaysia.

Finally, to investigate how investors react to analyst recommendations, we collect daily trading data for firms listed on the Korea Stock Exchange. We are not able to obtain trading data for the other seven countries because they are not publicly available. The advantage of the Korean dataset is that it allows us to unambiguously distinguish trades by investor type and thereby examine their trade reactions to analyst recommendations. The exchange labels investors as i) securities companies, ii) insurance companies, iii) investment trusts, iv) banks, v) other finance companies, vi) funds, vii) individuals, viii) foreigners, or ix) others. For our purposes, we aggregate the first six types of investors and refer to them as

\footnotetext{
${ }^{9}$ We use both the active and inactive stock files from Datastream to mitigate survivorship bias. In view of the practice that Datastream sets the return as a constant after a stock ceases trading, we treat those constant values as missing values in the inactive data file. In addition, to avoid recording errors in Datastream, we treat daily holding period returns that are greater than $100 \%$ as missing values.
} 
TABLE 1

Summary Statistics

Panel A of Table 1 reports the summary statistics for local and foreign brokerages in the eight countries we study from January 1994 through December 2003. Panel B reports the same set of statistics for subperiods. Number of Brokerages refers to the total number of brokerages making recommendations during the period. Number of Firms Covered refers to the total number of firms covered by each analyst group. Time-series and cross-sectional averages of year-end market capitalization (in USD millions) of firms covered by analysts are also reported. Number of Firms Covered per Analyst refers to the average number of firms covered by each analyst. Number of Analysts per Brokerage refers to the average number of worldwide analysts working for the brokerage. Analyst Experience denotes the average number of years an analyst has been covering the country since 1994. Number of Analyst Recommendations refers to the total number of recommendations made by the analyst group

\begin{tabular}{|c|c|c|c|c|c|c|c|c|c|c|c|c|c|c|}
\hline \multirow{2}{*}{$\begin{array}{l}\text { Country/ } \\
\text { Time } \\
\text { Periods }\end{array}$} & \multicolumn{2}{|c|}{$\begin{array}{l}\text { Number of } \\
\text { Brokerages }\end{array}$} & \multicolumn{2}{|c|}{$\begin{array}{l}\text { Number } \\
\text { of Firms } \\
\text { Covered }\end{array}$} & \multicolumn{2}{|c|}{$\begin{array}{c}\text { Average } \\
\text { Firm Size } \\
\text { (millions/USD) }\end{array}$} & \multicolumn{2}{|c|}{$\begin{array}{c}\text { Number of } \\
\text { Firms Covered } \\
\text { per Analyst }\end{array}$} & \multicolumn{2}{|c|}{$\begin{array}{c}\text { Number of } \\
\text { Analysts } \\
\text { per Brokerage }\end{array}$} & \multicolumn{2}{|c|}{$\begin{array}{l}\text { Analyst } \\
\text { Experience } \\
\text { (years) }\end{array}$} & \multicolumn{2}{|c|}{$\begin{array}{c}\text { Number of } \\
\text { Analyst } \\
\text { Recommendations }\end{array}$} \\
\hline & Local & Foreign & Local P & Foreign & Local & Foreign & Local & Foreign & Local & Foreign & Local & Foreign & Local & Foreign \\
\hline \multicolumn{15}{|c|}{ Panel A. Sample Statistics by Country } \\
\hline India & 22 & 31 & 330 & 407 & 783 & 704 & 4 & 5 & 7 & 167 & 1.7 & 2.1 & 2,932 & 9,719 \\
\hline Indonesia & 8 & 37 & 164 & 195 & 552 & 494 & 5 & 4 & 5 & 151 & 2.1 & 2.3 & 1,863 & 8,434 \\
\hline Korea & 30 & 31 & 1,038 & 567 & 394 & 793 & 9 & 4 & 15 & 183 & 1.8 & 2.0 & 17,935 & 10,211 \\
\hline Malaysia & 16 & 52 & 334 & 364 & 809 & 754 & 7 & 5 & 9 & 116 & 2.4 & 2.6 & 7,658 & 18,764 \\
\hline Philippines & 5 & 37 & 98 & 125 & 937 & 514 & 8 & 4 & 3 & 154 & 1.9 & 2.1 & 800 & 8,398 \\
\hline Singapore & 13 & 44 & 354 & 321 & 889 & 1,056 & 5 & 4 & 24 & 136 & 2.8 & 2.2 & 7,553 & 13,962 \\
\hline Taiw & 9 & 33 & 380 & 439 & 1,623 & 1,353 & 7 & 4 & 15 & 172 & 1.6 & 1.9 & 2,535 & 10,957 \\
\hline Thailand & 6 & 45 & 211 & 439 & 469 & 413 & 7 & 5 & 6 & 134 & 1.7 & 2.3 & 1,906 & 15,877 \\
\hline \multicolumn{15}{|c|}{ Panel B. Sample Statistics by Subperiod } \\
\hline 4-1997 & 41 & 53 & 1,550 & 2,181 & 1,035 & 717 & 6 & 6 & 21 & 113 & 1.8 & 1.9 & 9,552 & 40,619 \\
\hline $98-2000$ & 51 & 52 & 1,841 & 1,483 & 696 & 763 & 8 & 5 & 16 & 130 & 2.1 & 2.3 & 13,453 & 28,339 \\
\hline 2001-2003 & 84 & 33 & 1,880 & 1,331 & 668 & 815 & 6 & 4 & 14 & 157 & 2.1 & 2.5 & 20,177 & 27,364 \\
\hline 1994-2003 & 109 & 74 & 2,909 & 2,858 & 807 & 760 & 7 & 5 & 17 & 131 & 2.0 & 2.2 & 43,182 & 96,322 \\
\hline
\end{tabular}

domestic institutions. We refer to vii) as domestic retail investors and viii) as foreign investors, and we ignore ix). The Korean daily trading data are only available from January 1, 1995 onward.

As a prelude to analyzing analyst recommendations, we report the number and total market capitalization of domestic equity issues in the eight emerging countries grouped by managing underwriter location in Table A1. An equity issue is classified as Local Lead Underwriter if the sole managing underwriter is local or if all the joint managing underwriters are local. It is classified as Foreign Lead Underwriter otherwise. From Table A1, we confirm that domestic equity issues in emerging Asian markets are dominated by local underwriters. In every country, at least 78\% (by number) and 69\% (by market capitalization) of the equity issues are managed by local underwriters. The equity issue market is least dominated by local underwriters in Indonesia (possibly reflecting the underdeveloped local investment banking sector) and most dominated by local underwriters in Taiwan. The results in Table A1 indicate that emerging market equity issues are typically managed by local underwriters. This, in turn, points to the presence of cultural and language barriers facing foreign underwriters or to the less lucrative nature of underwriting in emerging countries. It also suggests that local analysts face greater investment banking pressures than do foreign analysts in these markets

\section{Empirical Tests}

In this section, we explore optimism differences between local and foreign analyst recommendations. Our analysis is motivated by the dominance of local 
underwriters in the equity issue markets in emerging countries. The dominance suggests that local analysts face stronger conflicts of interests than do foreign analysts. Hence, we hypothesize that local analyst recommendations are more optimistic than foreign analyst recommendations on emerging market stocks. In addition, such optimism differences may translate to differences in recommendation performance. Specifically, because local analysts are more eager to issue upgrades and more reluctant to issue downgrades, local upgrades should underperform foreign upgrades, while local downgrades should outperform foreign downgrades. Moreover, if international investors are not fully aware of such optimism differences, then they may have implications on international investor performance as well.

\section{A. Recommendation Optimism: Local versus Foreign Analysts}

The first order of business is to test for optimism differences between local and foreign analysts. We first examine the distribution of analyst recommendations. We report the number and proportion of analyst recommendations and recommendation changes for both local and foreign analysts in Table 2. We also test the null hypothesis that the differences in proportion are each equal to zero (assuming that all recommendations result from independent decisions). The recommendation level results in Panel A of Table 2 indicate that local analysts, relative to foreign analysts, appear to be more reluctant to issue sells than they are eager to issue buys and holds. The difference in proportion between local and foreign analyst recommendations is positive for buys and holds, but negative for sells. These differences are statistically different from zero at the $1 \%$ level of significance. ${ }^{10}$ We note, however, that the larger differences in proportion for holds and sells versus buys suggest that local analysts are more reluctant to issue pessimistic reports than they are eager to issue optimistic reports. For a different look at the optimism differences, we also calculate the average/median local and foreign consensus with the sample of stocks covered by both local and foreign analysts. In results not reported, we find that the average local consensus of 2.34 is statistically greater than the average foreign consensus of 2.23 ( $t$-statistic $=9.58$ ). Similarly, the median local consensus of 2.35 is statistically greater than the median foreign consensus of $2.27(t$-statistic $=14.59)$.

One concern is that if local analysts cover stocks with brighter future prospects than do foreign analysts, this may explain the apparent optimism among the former. To sidestep coverage issues, we employ the matching algorithm of Lin and McNichols (1998). For each local analyst recommendation, we find foreign analyst recommendations on the same stock within 60 days of the recommendation.

\footnotetext{
${ }^{10}$ The standard error used in the calculation of the $t$-statistic for the difference in the proportion of local buys versus foreign buys is

$$
\sqrt{\frac{P B L(1-P B L)}{n b_{l}+n h_{l}+n s_{l}}+\frac{P B F(1-P B F)}{n b_{f}+n h_{f}+n s_{f}}},
$$

where $n b_{l}, n h_{l}, n s_{l}, n b_{f}, n h_{f}$, and $n s_{f}$ are the number of local buys, local holds, local sells, foreign buys, foreign holds, and foreign sells, and $P B L$ and $P B F$ are the proportion of local buys and foreign buys. The standard errors used for the differences in proportion of local versus foreign holds and sells are calculated analogously.
} 
TABLE 2

Distribution of Analyst Recommendations

Summary statistics of analyst recommendations broken down by recommendation type. The first two columns report the number of local and foreign analyst recommendations. The third column reports the proportion of all local recommendations that are buys/holds/sells. The fourth column reports the same statistics for foreign recommendations. The fifth column reports the difference in proportion for local versus foreign analysts, while the sixth column reports the associated $t$-statistic. The sample period is from January 1994 to December 2003.

\begin{tabular}{|c|c|c|c|c|c|c|}
\hline \multirow[b]{2}{*}{ Recommendation } & \multicolumn{2}{|c|}{$\begin{array}{c}\text { Number of } \\
\text { Observations }\end{array}$} & \multicolumn{4}{|c|}{ Proportion } \\
\hline & Local & Foreign & Local & Foreign & Diff. & $t$-Stat. \\
\hline \multicolumn{7}{|l|}{ Panel A. Full Sample } \\
\hline $\begin{array}{l}\text { Buy } \\
\text { Hold } \\
\text { Sell }\end{array}$ & $\begin{array}{r}20,108 \\
15,426 \\
7,648\end{array}$ & $\begin{array}{l}44,080 \\
28,466 \\
23,776\end{array}$ & $\begin{array}{l}46.56 \% \\
35.72 \% \\
17.71 \%\end{array}$ & $\begin{array}{l}45.76 \% \\
29.55 \% \\
24.68 \%\end{array}$ & $\begin{array}{r}0.80 \% \\
6.17 \% \\
-6.97 \%\end{array}$ & $\begin{array}{r}2.77 \\
22.57 \\
-30.28\end{array}$ \\
\hline \multicolumn{7}{|l|}{ Panel B. Matched Sample } \\
\hline $\begin{array}{l}\text { Buy } \\
\text { Hold } \\
\text { Sell }\end{array}$ & $\begin{array}{r}10,532 \\
6,825 \\
3,775\end{array}$ & $\begin{array}{l}9,959 \\
5,881 \\
5,292\end{array}$ & $\begin{array}{l}49.84 \% \\
32.30 \% \\
17.86 \%\end{array}$ & $\begin{array}{l}47.13 \% \\
27.83 \% \\
25.04 \%\end{array}$ & $\begin{array}{r}2.71 \% \\
4.47 \% \\
-7.18 \%\end{array}$ & $\begin{array}{r}5.58 \\
10.03 \\
-18.04\end{array}$ \\
\hline
\end{tabular}

If there is more than one foreign recommendation, we match the foreign analyst recommendation that is issued closest to the date of the local analyst recommendation with the local analyst recommendation. If no foreign analyst recommendations are issued within 60 days of the local analyst recommendation, the local analyst recommendation is removed from the sample. Thus, we control for the characteristics of firms that local and foreign analysts choose to cover. This algorithm yields a matched sample of 21,132 local and 21,132 foreign analyst recommendations. We then report the differences for this matched sample of stock recommendations. The results in Panel B of Table 2 indicate that differences in coverage cannot explain the greater recommendation optimism of local analysts.

Yet another concern is that other analyst and brokerage attributes may conspire to increase (reduce) the recommendation optimism of local (foreign) analysts. For example, foreign analysts may belong to larger and more established brokerages. These analysts might then eschew optimism for greater accuracy so as not to tarnish their stellar reputations. To address this concern, we estimate pooled cross-sectional regressions on recommendation optimism (recommendation minus consensus recommendation) with the local analyst dummy as an independent variable. If local analysts are reliably more optimistic than their foreign counterparts, the coefficient estimate on the local analyst dummy should be statistically positive. To account for the effects that analyst, firm, and brokerage attributes may have on recommendation optimism, we include the log of firm size, number of analysts covering the firm, analyst experience, number of firms covered by the analyst, and brokerage size (which we proxy with the number of analysts issuing recommendations for the brokerage) as controls in the regressions. The firm characteristics proxy for investment banking and trade generation concerns, while the analyst characteristics proxy for analyst reputation and career concerns. As mentioned, brokerage size may capture analyst reputation effects. Firm size may also proxy for the level of institutional holdings that Ljungqvist et al. (2007) show has a moderating effect on recommendation optimism because institutions reward accurate analysts with higher performance ratings. We include yearly and coun- 
try dummies to capture variation in optimism over the sample period and across countries.

Concretely then, the regressions we estimate include:

$$
\begin{aligned}
& O P T_{i, k, t}=a+b L O C A L_{i, t}+\sum_{y r} h^{y r} Y R D U M_{t}^{y r} \\
& +\sum_{c t r y} j^{c t r y} C T R Y D U M_{k}^{c t r y}+\xi_{i, k, t}, \\
& O P T_{i, k, t}=a+b L O C A L_{i, t}+c \log \left(S I Z E_{k, t}\right) \\
& +\sum_{y r} h^{y r} Y R D U M_{t}^{y r}+\sum_{c t r y} j^{c t r y} C T R Y D U M_{k}^{c t r y}+\xi_{i, k, t}, \\
& O P T_{i, k, t}=a+b L O C A L_{i, t}+c \log \left(S I Z E_{k, t}\right) \\
& +d N A N A L Y S T_{k, t}+e E X P_{i, t}+\text { NNFIRM }_{i, t} \\
& +\sum_{y r} h^{y r} Y_{R D U M}^{y r}+\sum_{c t r y} j^{c t r y} C^{\text {CTRYDU }} M_{k}^{c t r y}+\xi_{i, k, t}, \quad \text { and } \\
& O P T_{i, k, t}=a+b L O C A L_{i, t}+c \log \left(S I Z E_{k, t}\right)+d N A N A L Y S T_{k, t} \\
& +e E X P_{i, t}+\text { fNFIRM }_{i, t}+g B R O K E R S I Z E_{i, t} \\
& +\sum_{y r} h^{y r} Y R D U M_{t}^{y r}+\sum_{c t r y} j^{c t r y} C T R Y D U M_{k}^{c t r y}+\xi_{i, k, t},
\end{aligned}
$$

where $O P T_{i, k, t}$ is the recommendation optimism (recommendation minus consensus recommendation) for analyst $i$ and firm $k$ in day $t, L O C A L$ is the local analyst dummy, SIZE is firm size, NANALYST is the number of analysts covering the firm, EXP is analyst experience in years, NFIRM is the number of firms covered by the analyst, BROKERSIZE is the brokerage size proxied by the number of analysts issuing recommendations for the brokerage, $Y R D U M^{y r}$ is the dummy for year, $y r,{ }^{11}$ and $C T R Y D U M^{\text {ctry }}$ is the dummy for country, ctry. For completeness, we also present results for the corresponding set of regressions without the yearly and country dummies, and for the matched sample as well.

The results reported in Panel A of Table 3 provide strong evidence that local analysts are more optimistic than foreign analysts. The OLS coefficient estimates on the local analyst dummy are positive and statistically significant ${ }^{12}$ for all regression models. This is true whether we include the yearly and country dummies. Because the standard deviation of the $O P T$ variable is 0.88 , the coefficient estimate for the most comprehensive equation (4) regression indicates that local analysts are 0.12 standard deviations more optimistic than foreign analysts. The only other independent variables that also display statistical significance across all model specifications and for both the full and matched sample are firm size, number of firms covered by analysts, yearly dummies, and country dummies. The reliably negative effect that firm size exerts on recommendation optimism is

\footnotetext{
${ }^{11}$ We also perform regressions without yearly dummies but with observations clustered by year and obtain qualitatively similar results. We thank Mark Seasholes for this suggestion.

${ }^{12}$ Statistical significance is measured using White (1980) heteroskedasticity-consistent standard errors. As additional robustness tests, we also reestimate the regressions using FGLS and MLE with firm-wide heteroskedasticity, as well as calculate the standard errors using the bootstrap. The results are very similar to these alternative specifications.
} 
consistent with the view expounded by Ljungqvist et al. (2007) that the level of institutional holdings has a moderating effect on recommendation optimism. The negative coefficients on the number of firms covered by the analyst variable may reflect a familiarity bias (Bailey, Kumar, and Ng (2006)) among analysts. The pattern of coefficient estimates on the yearly dummies accords with simple intuition. The coefficient estimates for the 1997 and 2000 dummies are large and statistically negative, reflecting the prevailing negative sentiment at the height of the Asian financial crisis ${ }^{13}$ and at the end of the technology bubble, respectively. Conversely, the coefficient estimates for the 1998 and 1999 dummies are large and statistically positive reflecting the positive sentiment during the technology bubble.

TABLE 3

\section{Regressions on Analyst Recommendation Optimism}

Pooled OLS regressions are estimated from January 1994 to December 2003 across all analyst recommendation/firm observations in the sample at that time. The dependent variable is analyst recommendation minus this month's median recommendation. Observations with consensus generated with less than three observations are excluded from the analysis. The recommendation variable takes the following values: $3=$ buy, 2 = hold, and $1=$ sell. Analyst experience is measured in years. All numbers for analysts and firms are in hundreds. The coefficients on the intercept and the country and yearly dummies are suppressed for brevity. The number of observations for each full sample equation (1) regression is 126,708. The number of observations for all of the other full sample regressions is 121,379 . The $t$-statistics derived using White (1980) standard errors are in parentheses. ${ }^{~}=$ significant at the $10 \%$ level, ${ }^{*}=$ significant at the $5 \%$ level, and ${ }^{\star \star}=$ significant at the $1 \%$ level.

\begin{tabular}{|c|c|c|c|c|c|c|c|c|}
\hline \multirow{2}{*}{$\begin{array}{l}\text { Independent } \\
\text { Variable }\end{array}$} & \multicolumn{4}{|c|}{$\begin{array}{l}\text { Without Country } \\
\text { or Yearly Dummies }\end{array}$} & \multicolumn{4}{|c|}{$\begin{array}{l}\text { With Full Set of Country } \\
\text { and Yearly Dummies }\end{array}$} \\
\hline & Eq. (1) & Eq. (2) & Eq. (3) & Eq. (4) & Eq. (1) & Eq. (2) & Eq. (3) & Eq. (4) \\
\hline \multicolumn{9}{|l|}{ Panel A. Full Sample } \\
\hline Local analyst dummy & $\begin{array}{l}0.145^{\star \star} \\
(27.76)\end{array}$ & $\begin{array}{l}0.113^{* *} \\
(20.65)\end{array}$ & $\begin{array}{l}0.121^{\star \star} \\
(21.21)\end{array}$ & $\begin{array}{l}0.109^{\star \star} \\
(15.98)\end{array}$ & $\begin{array}{l}0.145^{\star \star} \\
(24.92)\end{array}$ & $\begin{array}{l}0.116^{\star \star} \\
(19.13)\end{array}$ & $\begin{array}{l}0.116^{* *} \\
(18.78)\end{array}$ & $\begin{array}{l}0.104^{\star \star} \\
(14.00)\end{array}$ \\
\hline Log of firm size & & $\begin{array}{l}-0.051^{* *} \\
(-28.27)\end{array}$ & $\begin{array}{l}-0.052^{\star \star} \\
(-24.77)\end{array}$ & $\begin{array}{l}-0.052^{\star \star} \\
(-24.61)\end{array}$ & & $\begin{array}{l}-0.048^{\star \star} \\
(-25.53)\end{array}$ & $\begin{array}{l}-0.033^{* *} \\
(-13.94)\end{array}$ & $\begin{array}{l}-0.033^{\star \star} \\
(-13.87)\end{array}$ \\
\hline Analyst experience & & & $\begin{array}{l}0.001 \\
(0.95)\end{array}$ & $\begin{array}{l}0.002 \\
(1.07)\end{array}$ & & & $\begin{array}{l}-0.005^{\star \star} \\
(-3.20)\end{array}$ & $\begin{array}{l}-0.005^{\star \star} \\
(-3.14)\end{array}$ \\
\hline $\begin{array}{l}\text { Number of firms } \\
\text { covered by analyst }\end{array}$ & & & $\begin{array}{l}-0.021^{\star *} \\
(-4.89)\end{array}$ & $\begin{array}{l}-0.022^{* *} \\
(-5.13)\end{array}$ & & & $\begin{array}{l}-0.021^{* *} \\
(-4.67)\end{array}$ & $\begin{array}{l}-0.022^{\star \star} \\
(-4.91)\end{array}$ \\
\hline $\begin{array}{l}\text { Number of analysts } \\
\text { covering firm }\end{array}$ & & & $\begin{array}{l}-0.007 \\
(-0.16)\end{array}$ & $\begin{array}{l}-0.004 \\
(-0.09)\end{array}$ & & & $\begin{array}{l}-0.620^{* *} \\
(-11.77)\end{array}$ & $\begin{array}{l}-0.619^{\star \star} \\
(-11.76)\end{array}$ \\
\hline $\begin{array}{l}\text { Number of analysts } \\
\text { in brokerage }\end{array}$ & & & & $\begin{array}{l}-0.006^{\star \star} \\
(-3.39)\end{array}$ & & & & $\begin{array}{l}-0.005^{\star \star} \\
(-2.87)\end{array}$ \\
\hline \multicolumn{9}{|c|}{ Panel B. Matched Sample } \\
\hline Local analyst dummy & $\begin{array}{l}0.109^{\star \star} \\
(12.68)\end{array}$ & $\begin{array}{l}0.111^{* *} \\
(12.59)\end{array}$ & $\begin{array}{l}0.118^{\star \star} \\
(13.07)\end{array}$ & $\begin{array}{l}0.113^{\star \star} \\
(9.31)\end{array}$ & $\begin{array}{l}0.109^{\star \star} \\
(12.74)\end{array}$ & $\begin{array}{l}0.111^{\star \star} \\
(12.65)\end{array}$ & $\begin{array}{l}0.116^{\star *} \\
(12.89)\end{array}$ & $\begin{array}{l}0.115^{\star \star} \\
(9.47)\end{array}$ \\
\hline Log of firm size & & $\begin{array}{l}-0.049^{* *} \\
(-15.13)\end{array}$ & $\begin{array}{l}-0.056^{\star \star} \\
(-14.69)\end{array}$ & $\begin{array}{l}-0.056^{\star \star} \\
(-14.68)\end{array}$ & & $\begin{array}{l}-0.047^{\star \star} \\
(-13.94)\end{array}$ & $\begin{array}{l}-0.031^{* *} \\
(-7.32)\end{array}$ & $\begin{array}{l}-0.031^{\star \star} \\
(-7.32)\end{array}$ \\
\hline Analyst experience & & & $\begin{array}{l}0.000 \\
(0.01)\end{array}$ & $\begin{array}{l}0.000 \\
(0.01)\end{array}$ & & & $\begin{array}{l}-0.007^{*} \\
(-2.54)\end{array}$ & $\begin{array}{l}-0.007^{\star} \\
(-2.54)\end{array}$ \\
\hline $\begin{array}{l}\text { Number of firms } \\
\text { covered by analyst }\end{array}$ & & & $\begin{array}{l}-0.027^{\star \star} \\
(-3.79)\end{array}$ & $\begin{array}{l}-0.027^{* *} \\
(-3.83)\end{array}$ & & & $\begin{array}{l}-0.024^{\star *} \\
(-3.25)\end{array}$ & $\begin{array}{l}-0.024^{\star \star} \\
(-3.24)\end{array}$ \\
\hline $\begin{array}{l}\text { Number of analysts } \\
\text { covering firm }\end{array}$ & & & $\begin{array}{l}0.202^{\star \star} \\
(2.75)\end{array}$ & $\begin{array}{l}0.203^{\star \star} \\
(2.76)\end{array}$ & & & $\begin{array}{l}-0.609^{* *} \\
(-6.65)\end{array}$ & $\begin{array}{l}-0.609^{\star \star} \\
(-6.65)\end{array}$ \\
\hline $\begin{array}{l}\text { Number of analysts } \\
\text { in brokerage }\end{array}$ & & & & $\begin{array}{l}-0.003 \\
(-0.65)\end{array}$ & & & & $\begin{array}{r}0.000 \\
(-0.07)\end{array}$ \\
\hline
\end{tabular}

\footnotetext{
${ }^{13}$ To check that the Asian financial crisis does not unduly affect the results, we reestimate the regressions in Table 3 without the 1997 observations. The results are robust to dropping the 1997 observations from the sample.
} 
To sidestep coverage issues, we repeat the regression analysis on the sample of matched recommendations. The regression estimates on the local analyst dummy in Panel B of Table 3 indicate that coverage differences do not drive our results. ${ }^{14}$ To get a sense of the robustness of the results across countries and time periods, we reestimate the regressions for the last two model specifications (equations (3) and (4)) by country and by subperiod for the following periods: 19941997, 1998-2000, and 2001-2003. The results in Table 4 reveal that local analysts are more optimistic than foreign analysts for most countries and for all subperiods. Moreover, the difference in recommendation optimism is statistically greater than zero for six of the eight countries (under equation (4)) and for all subperiods. Consistent with the investment banking story, one of the two countries without more optimistic local analysts, i.e., Indonesia, is also the country where local underwriters dominate the least (see Table A1). Interestingly, while the introduction of measures by the U.S. Securities Exchange Commission in 2000 to regulate the analyst industry and the resulting increased media scrutiny on analysts have diminished the overall optimism level in the U.S. (Barber, Lehavy, McNichols, and Trueman (2006)), they have not diminished the optimism of local analysts relative to that of foreign analysts in emerging markets. The difference in optimism has remained fairly stable over the entire sample period.

There may be concerns that the optimism differences we uncover are confined to certain stocks. If, for example, the optimism differences are restricted to small and non-index stocks, our study may not be relevant to institutional investors who typically trade large index stocks. To address these concerns, we split the sample of firm observations into equal number groups by firm size and by the firm book-to-market ratio, and we reestimate the equation (3) and equation (4) regressions for each subsample separately. We do the same for stocks that belong to the MSCI World Free Index and those that do not belong to that index. The coefficients on the local analyst dummy and their $t$-statistics reported in Panel A of Table 5 make clear that the optimism differences are pervasive and robust across index, non-index, small, large, value, and growth stocks.

In addition, we examine the optimism differences for recommendations stratified by brokerage type. Specifically, we test whether the effects are confined to large brokerages that employ many analysts or to small brokerages that employ a few analysts. We also check whether the optimism differences are more acute with foreign analysts whose brokerages have a local presence or with foreign analysts whose brokerages do not have a local presence, and whether the optimism differences apply to U.S.-based or to non-U.S.-based foreign brokerages. The results in Panel B of Table 5 suggest that the optimism differences persist across brokerage types. In particular, the optimism differences are statistically significant with analysts from large brokerages who presumably have higher ability and with analysts from small brokerages who presumably have lower ability.

\footnotetext{
${ }^{14}$ In the matched sample, the coefficient estimate on the NANALYST variable changes its sign and significance depending on the inclusion of the year and country dummies. We find that this is mostly because in 1997, during the Asian financial crisis, the number of analysts covering each firm is very low and the average level of optimism is also low. To check this, we reestimate the equation (4) regression with full country dummies and a dummy for a particular year in the sample period. We do so 10 times, i.e., once for each year in the sample period. We find that NANALYST changes sign from positive to negative only when we include the dummy for 1997.
} 
TABLE 4

Recommendation Optimism of Local versus Foreign Analysts by Country and Subperiod

Coefficient estimates on the local analyst dummy from country by country and subperiod by subperiod OLS regressions are estimated from January 1994 to December 2003 across all analyst recommendation/firm observations in the sample at that time. The dependent variable is analyst recommendation minus this month's median recommendation. Observations with consensus generated with less than three observations are excluded from the analysis. The recommendation variable takes the following values: 3 = buy, 2 = hold, and $1=$ sell. The independent variables in equation (3) include local analyst dummy, log of firm size, analyst experience in years, number of firms covered per analyst, and number of analysts covering firm. Equation (4) includes, in addition, the independent variable number of analysts in the brokerage. The $t$-statistics derived using White (1980) standard errors are in parentheses. ${ }^{\wedge}=$ significant at the $10 \%$ level, ${ }^{*}=$ significant at the $5 \%$ level, and ${ }^{\star \star}=$ significant at the $1 \%$ level.

\begin{tabular}{|c|c|c|c|c|c|c|}
\hline \multirow[b]{2}{*}{$\begin{array}{l}\text { Country/ } \\
\text { Subperiod }\end{array}$} & \multicolumn{3}{|c|}{ Full Sample } & \multicolumn{3}{|c|}{ Matched Sample } \\
\hline & $\begin{array}{l}\text { Number } \\
\text { of Obs. }\end{array}$ & Eq. (3) & Eq. (4) & $\begin{array}{l}\text { Number } \\
\text { of Obs. }\end{array}$ & Eq. (3) & Eq. (4) \\
\hline \multicolumn{7}{|c|}{ Panel A. Country by Country Regressions } \\
\hline India & 10,518 & $\begin{array}{l}-0.037 \\
(-1.48)\end{array}$ & $\begin{array}{l}0.120^{* *} \\
(3.45)\end{array}$ & 3,799 & $\begin{array}{c}0.012 \\
(0.30)\end{array}$ & $\begin{array}{l}0.125^{*} \\
(2.15)\end{array}$ \\
\hline Indonesia & 9,000 & $\begin{array}{c}0.015 \\
(0.59)\end{array}$ & $\begin{array}{r}0.012 \\
(0.44)\end{array}$ & 2,598 & $\begin{array}{l}-0.022 \\
(-0.61)\end{array}$ & $\begin{array}{l}-0.003 \\
(-0.08)\end{array}$ \\
\hline Korea & 22,538 & $\begin{array}{l}0.108^{\star *} \\
(6.98)\end{array}$ & $\begin{array}{l}0.087^{\text {** }} \\
(3.67)\end{array}$ & 8,004 & $\begin{array}{l}0.112^{\star *} \\
(5.07)\end{array}$ & $\begin{array}{l}0.105^{* *} \\
(3.14)\end{array}$ \\
\hline Malaysia & 24,748 & $\begin{array}{c}0.174^{\star *} \\
(13.36)\end{array}$ & $\begin{array}{l}0.156^{\star \star} \\
(10.27)\end{array}$ & 9,636 & $\begin{array}{c}0.197^{\star \star} \\
(10.51)\end{array}$ & $\begin{array}{l}0.228^{* *} \\
(9.12)\end{array}$ \\
\hline Philippines & 8,389 & $\begin{array}{l}0.467^{\star \star} \\
(13.02)\end{array}$ & $\begin{array}{c}0.445^{\star \star} \\
(11.99)\end{array}$ & 1,206 & $\begin{array}{l}0.469^{\star \star} \\
(7.89)\end{array}$ & $\begin{array}{l}0.477^{\star \star} \\
(5.48)\end{array}$ \\
\hline Singapore & 19,803 & $\begin{array}{l}0.134^{\star *} \\
(10.11)\end{array}$ & $\begin{array}{l}0.130^{* *} \\
(8.20)\end{array}$ & 8,765 & $\begin{array}{l}0.137^{* *} \\
(7.50)\end{array}$ & $\begin{array}{l}0.131^{* *} \\
(5.47)\end{array}$ \\
\hline Taiwan & 11,417 & $\begin{array}{l}0.165^{\star *} \\
(7.21)\end{array}$ & $\begin{array}{l}0.132^{\star \star} \\
(4.81)\end{array}$ & 2,852 & $\begin{array}{l}0.165^{* *} \\
(4.29)\end{array}$ & $\begin{array}{l}0.107^{*} \\
(2.00)\end{array}$ \\
\hline Thailand & 14,966 & $\begin{array}{c}0.000 \\
(0.01)\end{array}$ & $\begin{array}{l}-0.017 \\
(-0.53)\end{array}$ & 2,245 & $\begin{array}{l}-0.046 \\
(-1.06)\end{array}$ & $\begin{array}{l}-0.031 \\
(-0.56)\end{array}$ \\
\hline \multicolumn{7}{|c|}{ Panel B. Subperiod by Subperiod Regressions } \\
\hline 1994-1997 & 42,051 & $\begin{array}{l}0.118^{\star *} \\
(10.17)\end{array}$ & $\begin{array}{l}0.071^{\star \star} \\
(5.47)\end{array}$ & 11,767 & $\begin{array}{l}0.132^{\star \star} \\
(8.25)\end{array}$ & $\begin{array}{l}0.096^{* *} \\
(4.56)\end{array}$ \\
\hline 1998-2000 & 37,467 & $\begin{array}{l}0.117^{\star \star} \\
(9.94)\end{array}$ & $\begin{array}{l}0.125^{\star \star} \\
(9.00)\end{array}$ & 13,105 & $\begin{array}{l}0.104^{* *} \\
(6.28)\end{array}$ & $\begin{array}{l}0.126^{* *} \\
(5.45)\end{array}$ \\
\hline 2001-2003 & 41,861 & $\begin{array}{c}0.110^{\star \star} \\
(11.30)\end{array}$ & $\begin{array}{l}0.112^{\star \star} \\
(9.06)\end{array}$ & 14,233 & $\begin{array}{l}0.103^{* *} \\
(7.17)\end{array}$ & $\begin{array}{l}0.105^{\star *} \\
(5.22)\end{array}$ \\
\hline
\end{tabular}

The coefficient estimates in columns three and four of Panel B also indicate that the optimism difference between local and foreign analysts with local presence is smaller than that between local and foreign analysts without local presence. This in turn suggests that among foreign analysts, those with local presence are more optimistic than those without local presence. One reason may be that foreign brokerages with a local presence get a disproportionate amount of the underwriting business allocated to foreign brokerages. We also find that U.S. analysts are more optimistic than non-U.S. foreign analysts, though U.S. analysts are still less optimistic relative to local analysts.

\section{B. Recommendation Performance}

In this section, we test the implications of the relative optimism uncovered in the previous section on the cumulative market-adjusted abnormal returns following local and foreign analyst recommendations. We analyze the returns accruing to the stocks that have buy, hold, or sell recommendations as well as stocks that have been upgraded to a buy or downgraded to a sell. Our analysis focuses on the 


\section{TABLE 5}

Recommendation Optimism of Local versus Foreign Analysts by Firm and Brokerage Type

Pooled OLS regressions are estimated from January 1994 to December 2003 across all analyst recommendation/firm observations in samples broken down by firm and brokerage type. The dependent variable is analyst recommendation minus this month's median recommendation. Observations with consensus generated with less than three observations are excluded from the analysis. In the equation (3) regressions, the independent variables are the local analyst dummy, log of firm size, analyst experience, number of analysts covering the firm, and number of firms covered per analyst. In the equation (4) regressions, the number of analysts working for the brokerage is also included as an additional independent variable. The recommendation variable takes the following values: $3=$ buy, $2=$ hold, and $1=$ sell. Firms are split into groups based on inclusion/non-inclusion in the MSCI World Free Index as of December 2003. Firm observations are also split into equal groups based on firm size and on the firm book-to-market ratio. Brokerages are split into small and large brokerages based on the number of analysts employed, such that the number of small and large local brokerages are the same, and the number of small and large foreign brokerages are the same. Foreign brokerages are also split into groups based on local presence and whether they are based in the U.S. The $t$-statistics derived using White (1980) standard errors are in parentheses. ${ }^{\wedge}=$ significant at the $10 \%$ level, ${ }^{\star}=$ significant at the $5 \%$ level, ${ }^{\star \star}=$ significant at the $1 \%$ level.

Panel A. Grouped by Firm Type

\begin{tabular}{|c|c|c|c|c|c|c|}
\hline \multirow[b]{2}{*}{ Coefficient on local analyst dummy in: } & \multicolumn{6}{|c|}{ Firm Type } \\
\hline & $\begin{array}{l}\mathrm{MSCl} \\
\text { Index }\end{array}$ & $\begin{array}{l}\text { Non- } \\
\text { Index }\end{array}$ & Large & Small & Growth & Value \\
\hline Equation (3) regression & $\begin{array}{l}0.120^{\star \star} \\
(13.86)\end{array}$ & $\begin{array}{c}0.116^{* *} \\
(13.03)\end{array}$ & $\begin{array}{c}0.133^{\star *} \\
(15.40)\end{array}$ & $\begin{array}{c}0.102^{\star *} \\
(11.37)\end{array}$ & $\begin{array}{c}0.101^{\star *} \\
(11.35)\end{array}$ & $\begin{array}{l}0.130^{* *} \\
(13.88)\end{array}$ \\
\hline Equation (4) regression & $\begin{array}{c}0.117^{\star \star} \\
(11.27)\end{array}$ & $\begin{array}{l}0.095^{* *} \\
(8.91)\end{array}$ & $\begin{array}{c}0.123^{\star *} \\
(11.80)\end{array}$ & $\begin{array}{l}0.093^{\star \star} \\
(8.65)\end{array}$ & $\begin{array}{l}0.080^{\star *} \\
(7.44)\end{array}$ & $\begin{array}{l}0.131^{\star \star} \\
(11.65)\end{array}$ \\
\hline \multicolumn{7}{|l|}{ Panel B. Grouped by Brokerage Type } \\
\hline & \multicolumn{2}{|c|}{ All Brokerage Types } & \multicolumn{4}{|c|}{ Foreign Brokerage Type } \\
\hline Coefficient on local analyst dummy in: & Large & Small & $\begin{array}{c}\text { Local } \\
\text { Presence }\end{array}$ & $\begin{array}{c}\text { No } \\
\text { Presence }\end{array}$ & U.S. & Non-U.S. \\
\hline Equation (3) regression & $\begin{array}{c}0.111^{\star \star} \\
(12.25)\end{array}$ & $\begin{array}{c}0.148^{* *} \\
(16.36)\end{array}$ & $\begin{array}{c}0.107^{\text {** }} \\
(15.30)\end{array}$ & $\begin{array}{l}0.129 * * \\
(17.71)\end{array}$ & $\begin{array}{l}0.080^{* *} \\
(9.07)\end{array}$ & $\begin{array}{c}0.124^{\text {** }} \\
(18.98)\end{array}$ \\
\hline Equation (4) regression & $\begin{array}{c}0.172^{\star \star} \\
(10.98)\end{array}$ & $\begin{array}{l}0.097^{* *} \\
(8.93)\end{array}$ & $\begin{array}{l}0.095^{\star *} \\
(10.62)\end{array}$ & $\begin{array}{c}0.120^{* \star} \\
(12.35)\end{array}$ & $\begin{array}{l}0.050^{* *} \\
(2.78)\end{array}$ & $\begin{array}{c}0.107^{* *} \\
(13.77)\end{array}$ \\
\hline
\end{tabular}

announcement day as well as one week, one month, and two months following the announcement to gauge the information content of the recommendation.

If the pattern of cumulative abnormal returns (CARs) is consistent with the optimism results in the previous section, then local analyst buys should underperform foreign analyst buys while local analyst sells should outperform foreign analyst sells. The underlying intuition is that local analysts are more eager to issue buy calls on local stocks. As a result, foreign buy calls contain more positive information. Conversely, local analysts are more reluctant to issue sell calls on local stocks. As a result, local sell calls contain more negative information. If, however, the pattern of CARs is consistent with local analysts having an informational advantage over foreign analysts through geographical proximity (Hau (2001), Malloy (2005), and Choe, Kho, and Stulz, (2005)), then the local buys/sells should outperform foreign buys/sells. Conversely, if foreign analysts, who might have greater expertise and access to better resources, possess informational advantages over local analysts (Seasholes (2006), Grinblatt and Keloharju (2000)), then local buys/sells should underperform foreign buys/sells. An analysis of the pattern in CARs thus allows us to discriminate between the relative optimism and the informational advantage stories.

The pattern of CARs reported in Table 6 is broadly consistent with local analysts being more optimistic than foreign analysts. Buys and holds issued by local analysts underperform buys and holds issued by foreign analysts for all horizons. 
Conversely, sells issued by local analysts outperform sells issued by foreign analysts for all horizons tested. Similar results are obtained with upgrades to buy and downgrades to sell. Moreover, differences in the CAR following local and foreign analyst recommendations are almost always statistically significant. For example, during the announcement day, local buys underperform foreign buys by 24 basis points, while local sells outperform foreign sells by -22 basis points. Both differences are statistically significant at the $1 \%$ level. Moreover, the announcement day return spread between a foreign analyst buy and a local analyst sell is an economically significant $1.09 \%$, outperforming the spread between foreign buys and sells and the spread between local buys and sells. In fact, the same result holds over all horizons and with upgrades/downgrades as well. To sidestep coverage issues, we also redo the CAR analysis on the sample of matched firms and obtain similar results.

It is intriguing to note that contrary to studies on analyst recommendations in the U.S. that show that buy recommendations on U.S. stocks have less informational content than sell recommendations (see Womack (1996), Barber, Lehavy, McNichols, and Trueman (2001)), the absolute CARs following a foreign analyst buy or upgrade are greater than those following a foreign analyst sell or downgrade for emerging market stocks (see the point estimates in columns five to eight of Table 6). This sharply contrasts with the informational content of U.S. stock recommendations. One reason for the dissonance may be that the investment banking-induced incentive to bias recommendations on U.S. stocks does not apply as strongly to emerging market stocks, at least for foreign analysts.

Given that cross-sectional dependence issues may bias test statistics for the abnormal performance measures calculated above (see Mitchell and Stafford (2000)), we also examine the performance of calendar-based portfolios. The calendar time portfolio approach has its own drawbacks that motivate using both approaches. According to Loughran and Ritter (2000), the calendar time portfolio approach has lower power to detect abnormal performance when it exists mostly in periods of high event activity. Our calendar time portfolio approach follows that of Barber, Lehavy, and Trueman (2007). We form five portfolios for each group of analysts (local and foreign): a buy portfolio, a hold portfolio, a sell portfolio, an upgrade to buy portfolio, and a downgrade to sell portfolio.

To understand how these portfolios are constructed, take the buy portfolio as an example. For each local analyst in the database, we identify initiations and reiterations of buy recommendations. For each of these recommendations, the recommended stock enters the buy portfolio at the close of the trading day of the announcement. Each recommended stock remains in the portfolio until the stock is downgraded or dropped from coverage by the analyst (we assume this occurs when recommendations have not been updated after 240 days). If more than one analyst recommends a particular stock on a given date, then that stock appears multiple times in the portfolio on that date, one for each buy recommendation (see Barber, Lehavy, and Trueman (2007) for more details on the construction of the calendar time portfolios). 


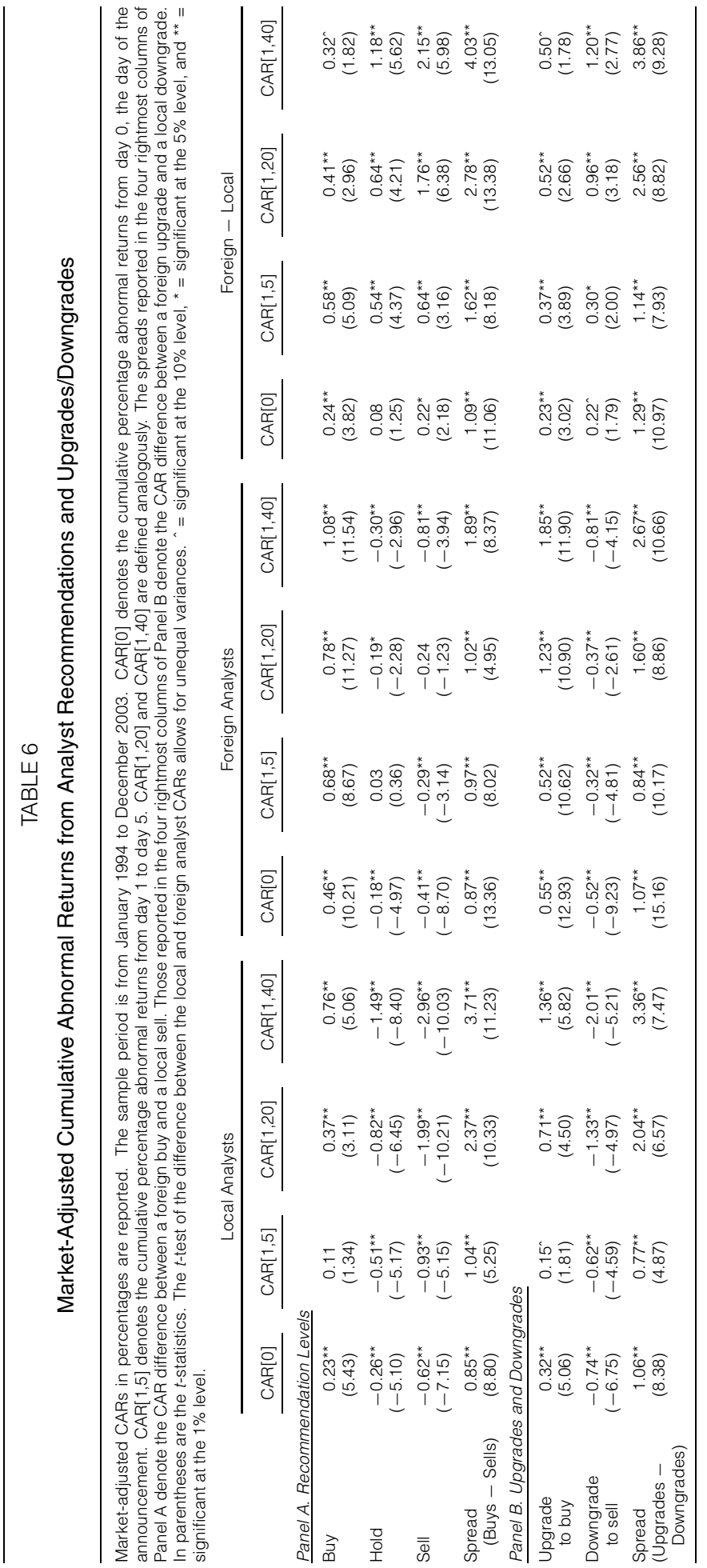


Next, we estimate performance relative to the CAPM, the Fama and French (1993) three-factor model, and the Carhart (1997) four-factor model:

$$
\begin{aligned}
r_{i t} & =\alpha_{i}+\beta_{i} R M R F_{i}+e_{i t}, \\
r_{i t} & =\alpha_{i}+\beta_{i} R M R F_{i}+s_{i} \operatorname{SMB}_{i}+h_{i} H M L_{i}+e_{i t},
\end{aligned}
$$

and

$$
r_{i t}=\alpha_{i}+\beta_{i} R M R F_{i}+s_{i} S M B_{i}+h_{i} H M L_{i}+p_{i} P R 1 Y R_{i}+e_{i t},
$$

where $t=1, \ldots, T, r_{i t}$ is the daily return on calendar time portfolio $i$ in excess of the risk-free rate, $R M R F$ is the excess return on a value-weighted aggregate market proxy, and $S M B, H M L$, and $P R 1 Y R$ are returns on a value-weighted, zero investment, factor-mimicking portfolio for size, book-to-market equity, and a oneyear momentum in stock returns. The four-factor model adds to the three-factor model a momentum factor, $P R 1 Y R$, that captures the Jegadeesh and Titman (1993) one-year momentum anomaly. The Fama and French (1993) factors are calculated in the same way as in Fama and French (1998). For example, to form the SMB factor, we rank all sample firms in each country in descending order by their market capitalization at the end of each year. Then, we form a large-cap portfolio with the top $30 \%$ of stocks and a small-cap portfolio with the bottom $30 \%$ of stocks. Then, we calculate the value-weighted daily returns of each portfolio. The country $S M B$ portfolio is the difference between the return on the small-cap portfolio and the return on the large-cap portfolio. The $S M B$ factor we use is a value-weighted country $S M B$ factor in which the weights are based on the stock market capitalizations of the eight countries in the sample.

The abnormal returns of the calendar time portfolios reported in Table 7 broadly corroborate the results from the CAR analysis. However, while local analyst buys/holds still underperform foreign analyst buys/holds, the difference in performance is no longer statistically significant at the $10 \%$ level. Nonetheless, local analyst sells continue to reliably outperform foreign analyst sells by -3.4 basis points per day or $-8.16 \%$ per year $(t$-statistic $=1.96)$ after adjusting for return covariation with the Fama and French (1993) factors. Sharper results emerge from the analysis of analyst recommendation changes. After adjusting for return covariation with the Fama and French factors, local analyst upgrades underperform foreign analyst upgrades by 3 basis points per day or $7.2 \%$ annualized, while local analyst downgrades outperform foreign analyst downgrades by -5.9 basis points per day or $-14.2 \%$ annualized. Both spreads are statistically significant at the $1 \%$ level.

The weaker results for buy recommendations are consistent with the distribution of recommendation levels reported in Table 2, where the difference in proportion is more striking for sells than for buys. The stronger results for the recommendation changes with the calendar time approach are also consistent with the results from other U.S. studies that show recommendation changes contain more information than recommendation levels. It is also comforting to note from Panel F of Table 7 that the strategy that buys foreign upgrades and short sells local downgrades outperforms strategies based solely on local recommendation changes or solely on foreign recommendation changes. These results neatly complement the 
upgrade/downgrade spread results in Panel B of Table 6. Overall, the calendar time portfolio analysis provides additional evidence on the underperformance of local analyst upgrades and the overperformance of local analyst sells/downgrades. It also echoes the results of Barber, Lehavy, and Trueman (2007) who analyze the recommendation performance of two groups of analysts facing different investment banking pressure: analysts from U.S. investment banks and analysts working at independent U.S. research firms.

\section{Trade Reaction to Analyst Recommendations}

According to The Wall Street Journal, July 14, 1992, Morgan Stanley asserts that customers of its equity research reports are too sophisticated to accept research influenced by investment banking pressure. In this section, we test whether sophisticated foreign investors, local institutions, and local retail investors recognize the full extent of the bias among local analysts. As Michaely and Womack ((2005) p. 410) put it, "if investors are aware of this marketing bias and discount it appropriately, then, to some extent, no harm is done."

To see whether "no harm is done," we analyze the trade reactions of investors grouped by investor type on the Korea Stock Exchange to local and foreign analyst recommendations and upgrades/downgrades. The Korea Stock Exchange provides access to daily net buys grouped by investor types for all stocks traded on the exchange. Our analysis focuses on the standardized trade imbalance (our proxy for buying pressure) by investor type on day 0 to day 1 of the recommendation where day 0 is the day of the recommendation announcement. The standardized trade imbalance ${ }^{15}$ for firm $i$, investor type $x$, and date $t$ is

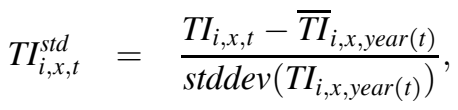

where

$$
T I_{i, x, t}=\frac{\text { buy_volume }_{i, x, t}-\text { sell_volume }_{i, x, t}}{\text { buy_volume }_{i, x, t}+\text { sell_volume }_{i, x, t}} .
$$

The variables $\overline{T I}_{i, x, \text { year }(t)}$ and $\operatorname{stddev}\left(T I_{i, x, \text { year }(t)}\right)$ are the mean and standard deviation of $T I$ or trade imbalance for firm $i$, investor type $x$, over year $t$, respectively.

Our use of the standardized trade imbalance follows Malmendier and Shanthikumar (2006) and adjusts for firm and year fixed effects as well as systematic volatility differences in large and small stocks. This facilitates comparison of trade imbalance across time, firms, and investor types. To gauge the trade reaction to recommendations, we estimate two sets of regressions for each investor type. First, we regress standardized trade imbalance on buy, hold, and sell dummies. Second, we regress the standardized trade imbalance on upgrade and downgrade dummies.

\footnotetext{
${ }^{15}$ The standardized trade imbalances are based on the number of shares bought and sold. We also redo the analysis using standardized trade imbalance based on the value of shares bought and sold. Our results are almost identical with this alternate calculation of standardized trade imbalance. The results are also virtually identical when we use abnormal trade imbalance or $T I_{i, x, t}-\overline{T I}_{i, x, y e a r(t)}$ instead of standardized trade imbalance.
} 
The results from the analysis of the standardized trade imbalance, reported in Table 8, are striking. First, in response to buy recommendations and upgrades, sophisticated foreign investors and local institutions buy while local retail investors sell. Conversely, in response to analyst sell recommendations and downgrades, foreign investors and local institutions sell while local retail investors buy. These effects are statistically different from zero for the average recommendation for retail investors and local institutions, and may help explain the overperformance of institutions and underperformance of retail investors in emerging markets (see, for instance, Barber, Lee, Liu, and Odean (2006)).

Second, local institutions react more to local analyst reports while foreign investors react more to foreign analyst reports. The standardized trade imbalances of local institutions in response to local analyst buys, holds, sells, and downgrades are larger in magnitude than their standardized trade imbalances in response to foreign analyst buys, holds, sells, and downgrades, respectively. On the other hand, the standardized trade imbalances of foreign investors in response to local analyst recommendations are smaller in magnitude than their trade imbalances in response to foreign analyst recommendations. This is not surprising given that local analyst recommendations are more accessible to local institutions while foreign analyst recommendations are more accessible to foreign institutions.

Third, despite the optimistic nature of local analyst recommendations, local institutions buy more after a local buy recommendation than they sell after a local sell recommendation. While they do react in the correct fashion to local holds, their marked response to local buys (standardized trade imbalance $=0.065$ ) relative to local sells (standardized trade imbalance $=-0.044$ ) indicates that they do not fully internalize the bias in local analyst recommendations.

Fourth, foreign investors appear to trade on the belief that foreign analyst recommendations are positively biased. Despite the fact that foreign analyst buys and upgrades possess greater informational content (insofar as reflected in the CAR results of Table $6^{16}$ ) than do foreign analyst sells and downgrades, respectively, foreign investors react more to foreign sells and downgrades than to foreign buys and upgrades. Following a foreign analyst sell call, foreign investors react with a standardized trade imbalance of -0.127 , which is more than twice as large in absolute terms as that following foreign analyst buy calls (standardized trade imbalance $=0.057$ ). One view is that the belief, formed over U.S. stock recommendations, that sells are more informative than buys (Womack (1996)) is so ingrained among foreign investors that it influences their trades in emerging market stocks as well.

Fifth, neither the sophisticated foreign investors nor the local institutions appear fully aware of the optimism differences between foreign and local analysts. Despite the evidence showing that local sells convey more negative information

\footnotetext{
${ }^{16}$ We believe that the CAR results are more relevant for the trade reaction analysis over day 0 to 1. This is because the CAR analysis better captures the short-term returns following analyst announcements than does the calendar time portfolio analysis. The CAR results in Table 6 are based on the full sample of countries. We also estimate the CARs for the sample of stocks on the Korean Stock Exchange. While the statistical significance of the results falls naturally with the reduced sample size, the pattern of CARs for the stocks in the Korean Stock Exchange is very similar to that for the full sample of countries.
} 


\section{TABLE 7}

\section{Calendar Time Portfolio Analysis of Local and Foreign Analyst Recommendations}

Table 7 reports the average daily percentage buy and hold return/market-adjusted return/abnormal return for portfolios of buy, hold, and sell recommendations, as well as upgrades to buy and downgrades to sell. To obtain the CAPM abnormal return, portfolio excess return is regressed on a constant and RMRF. To obtain the Fama-French abnormal return, portfolio excess return is regressed on a constant, RMRF, SMB, and HML. To obtain the four-factor abnormal return, portfolio excess return is regressed on a constant, RMRF, SMB, HML, and PR1YR. RMRF is the excess return on a value-weighted aggregate market proxy, and $S M B, H M L$, and $P R 1 Y R$ are returns on value-weighted, zero investment, factor-mimicking portfolios for size, book-to-market equity, and one-year momentum in stock returns. The sample period is from January 1994 to December $2003 .{ }^{\wedge}=$ significant at the $10 \%$ level, ${ }^{*}=$ significant at the $5 \%$ level, and ${ }^{* *}=$ significant at the $1 \%$ level.

\begin{tabular}{|c|c|c|c|c|}
\hline \multirow{3}{*}{ Panel A. Buy Recommendations } & \multirow{3}{*}{$\begin{array}{c}\text { Raw } \\
\text { Return }\end{array}$} & \multicolumn{3}{|c|}{ Abnormal Return } \\
\hline & & \multirow[t]{2}{*}{ CAPM } & \multirow[t]{2}{*}{$\begin{array}{l}\text { Fama- } \\
\text { French }\end{array}$} & \multirow[t]{2}{*}{$\begin{array}{c}\text { Four-Factor } \\
\text { Model }\end{array}$} \\
\hline & & & & \\
\hline Local & $\begin{array}{l}0.044^{\star} \\
(1.98)\end{array}$ & $\begin{array}{c}0.020 \\
(0.91)\end{array}$ & $\begin{array}{c}0.017 \\
(0.80)\end{array}$ & $\begin{array}{c}0.018 \\
(0.81)\end{array}$ \\
\hline Foreign & $\begin{array}{l}0.048^{\star} \\
(2.52)\end{array}$ & $\begin{array}{c}0.025 \\
(1.32)\end{array}$ & $\begin{array}{c}0.023 \\
(1.23)\end{array}$ & $\begin{array}{c}0.023 \\
(1.22)\end{array}$ \\
\hline Foreign - Local & $\begin{array}{c}0.005 \\
(0.51)\end{array}$ & $\begin{array}{c}0.005 \\
(0.54)\end{array}$ & $\begin{array}{c}0.006 \\
(0.64)\end{array}$ & $\begin{array}{c}0.005 \\
(0.58)\end{array}$ \\
\hline \multicolumn{5}{|l|}{ Panel B. Hold Recommendations } \\
\hline Local & $\begin{array}{c}0.004 \\
(0.16)\end{array}$ & $\begin{array}{l}-0.019 \\
(-0.74)\end{array}$ & $\begin{array}{l}-0.023 \\
(-0.86)\end{array}$ & $\begin{array}{l}-0.021 \\
(-0.81)\end{array}$ \\
\hline Foreign & $\begin{array}{c}0.013 \\
(0.64)\end{array}$ & $\begin{array}{l}-0.011 \\
(-0.54)\end{array}$ & $\begin{array}{l}-0.013 \\
(-0.69)\end{array}$ & $\begin{array}{l}-0.012 \\
(-0.63)\end{array}$ \\
\hline Foreign - Local & $\begin{array}{c}0.009 \\
(0.55)\end{array}$ & $\begin{array}{c}0.009 \\
(0.57)\end{array}$ & $\begin{array}{c}0.009 \\
(0.59)\end{array}$ & $\begin{array}{c}0.009 \\
(0.58)\end{array}$ \\
\hline \multicolumn{5}{|l|}{ Panel C. Sell Recommendations } \\
\hline Local & $\begin{array}{l}-0.039 \\
(-1.45)\end{array}$ & $\begin{array}{l}-0.062^{*} \\
(-2.36)\end{array}$ & $\begin{array}{l}-0.066^{*} \\
(-2.52)\end{array}$ & $\begin{array}{l}-0.064^{*} \\
(-2.44)\end{array}$ \\
\hline Foreign & $\begin{array}{l}-0.005 \\
(-0.22)\end{array}$ & $\begin{array}{l}-0.028 \\
(-1.26)\end{array}$ & $\begin{array}{l}-0.032 \\
(-1.44)\end{array}$ & $\begin{array}{l}-0.030 \\
(-1.35)\end{array}$ \\
\hline Foreign - Local & $\begin{array}{c}0.034 \\
(1.94)\end{array}$ & $\begin{array}{c}0.034^{\wedge} \\
(1.94)\end{array}$ & $\begin{array}{l}0.034^{\star} \\
(1.96)\end{array}$ & $\begin{array}{c}0.034^{\wedge} \\
(1.93)\end{array}$ \\
\hline \multicolumn{5}{|l|}{ Panel D. Upgrade to Buy } \\
\hline Local & $\begin{array}{l}0.052^{\star} \\
(2.22)\end{array}$ & $\begin{array}{c}0.028 \\
(1.23)\end{array}$ & $\begin{array}{c}0.026 \\
(1.11)\end{array}$ & $\begin{array}{c}0.026 \\
(1.11)\end{array}$ \\
\hline Foreign & $\begin{array}{l}0.081^{\star \star} \\
(4.09)\end{array}$ & $\begin{array}{l}0.058^{\star \star} \\
(2.97)\end{array}$ & $\begin{array}{l}0.056^{\star \star} \\
(2.88)\end{array}$ & $\begin{array}{l}0.056^{\star *} \\
(2.86)\end{array}$ \\
\hline Foreign - Local & $\begin{array}{l}0.029^{\star} \\
(2.54)\end{array}$ & $\begin{array}{l}0.030^{*} \\
(2.57)\end{array}$ & $\begin{array}{l}0.030^{\star \star} \\
(2.63)\end{array}$ & $\begin{array}{l}0.030 \text { ** } \\
(2.60)\end{array}$ \\
\hline \multicolumn{5}{|l|}{ Panel E. Downgrade to Sell } \\
\hline Local & $\begin{array}{l}-0.081^{\star \star} \\
(-3.15)\end{array}$ & $\begin{array}{l}-0.105^{\star \star} \\
(-4.11)\end{array}$ & $\begin{array}{l}-0.108^{\star *} \\
(-4.27)\end{array}$ & $\begin{array}{l}-0.106^{\star \star} \\
(-4.17)\end{array}$ \\
\hline Foreign & $\begin{array}{l}-0.028 \\
(-1.22)\end{array}$ & $\begin{array}{l}-0.051^{*} \\
(-2.27)\end{array}$ & $\begin{array}{l}-0.055^{\star} \\
(-2.46)\end{array}$ & $\begin{array}{l}-0.053^{*} \\
(-2.36)\end{array}$ \\
\hline Foreign - Local & $\begin{array}{l}0.059^{* *} \\
(3.75)\end{array}$ & $\begin{array}{l}0.060^{\star \star} \\
(3.76)\end{array}$ & $\begin{array}{l}0.059^{\star \star} \\
(3.76)\end{array}$ & $\begin{array}{l}0.059^{* *} \\
(3.72)\end{array}$ \\
\hline \multicolumn{5}{|c|}{ Panel F. Long Upgrade to Buy, Short Downgrade to Sell } \\
\hline Long local upgrade, short local downgrade & $\begin{array}{c}0.137^{\text {** }} \\
(11.38)\end{array}$ & $\begin{array}{c}0.137^{\star *} \\
(11.38)\end{array}$ & $\begin{array}{c}0.137^{\star *} \\
(11.42)\end{array}$ & $\begin{array}{c}0.136 \text { ** } \\
(11.28)\end{array}$ \\
\hline Long foreign upgrade, short foreign downgrade & $\begin{array}{c}0.109^{\text {** }} \\
(11.91)\end{array}$ & $\begin{array}{l}0.109^{* *} \\
(11.86)\end{array}$ & $\begin{array}{c}0.110^{\text {** }} \\
(12.18)\end{array}$ & $\begin{array}{l}0.109^{* *} \\
(11.93)\end{array}$ \\
\hline Long foreign upgrade, short local downgrade & $\begin{array}{c}0.165^{\star \star} \\
(10.31)\end{array}$ & $\begin{array}{c}0.165^{\text {** }} \\
(10.31)\end{array}$ & $\begin{array}{c}0.166^{\star \star} \\
(10.39)\end{array}$ & $\begin{array}{c}0.164^{\star *} \\
(10.24)\end{array}$ \\
\hline
\end{tabular}


TABLE 8

Trade Reaction to Analyst Recommendations by Investor Type

Table 8 reports the trade reaction for Korean stocks (Korean Stock Exchange) grouped by investor type and analyst recommendation type from day 0 to day 1 inclusive, where day 0 denotes the day of the recommendation. Investor types include foreign investors, local institutions, and local retail investors. Panel A reports the coefficient estimates on the buy, hold, and sell dummies when standardized trade imbalance is regressed on the buy, hold, and sell dummies. The regressions are estimated separately for each investor type. Panel B reports the coefficient estimates on the upgrade and downgrade dummies when standardized trade imbalance is regressed on the upgrade and downgrade dummies. Upgrades denote upgrades to buy. Downgrades denote downgrades to sell. As in Panel A, the regressions are estimated separately for each investor type. Trade imbalance is net buys divided by total buys and sells. Standardized trade imbalance is trade imbalance minus mean trade imbalance divided by standard deviation of trade imbalance, where the mean and standard deviation are calculated over the year for each firm and investor type. The $t$-statistics derived using White (1980) standard errors are in parentheses. ${ }^{\star}=$ significant at the $10 \%$ level, ${ }^{*}=$ significant at the $5 \%$ level, and ${ }^{\star *}=$ significant at the $1 \%$ level.

Panel A. Coefficient Estimates on Buy/Hold/Sell Dummies in Regression on Standardized Trade Imbalance

\begin{tabular}{|c|c|c|c|c|c|c|c|c|c|}
\hline \multirow[b]{2}{*}{ Investor Type: } & \multicolumn{3}{|c|}{ All Analysts } & \multicolumn{3}{|c|}{ Local Analysts } & \multicolumn{3}{|c|}{ Foreign Analysts } \\
\hline & Buy & Hold & Sell & Buy & Hold & Sell & Buy & Hold & Sell \\
\hline Foreign investors & $\begin{array}{l}0.028^{\star} \\
(2.01)\end{array}$ & $\begin{array}{l}-0.007 \\
(-0.45)\end{array}$ & $\begin{array}{l}-0.028 \\
(-1.52)\end{array}$ & $\begin{array}{c}0.006 \\
(0.34)\end{array}$ & $\begin{array}{c}0.010 \\
(0.56)\end{array}$ & $\begin{array}{l}0.046^{*} \\
(2.08)\end{array}$ & $\begin{array}{l}0.057^{* *} \\
(2.75)\end{array}$ & $\begin{array}{l}-0.042 \\
(-1.59)\end{array}$ & $\begin{array}{l}-0.127^{\star \star} \\
(-3.93)\end{array}$ \\
\hline Local institutions & $\begin{array}{l}0.051^{* *} \\
(3.30)\end{array}$ & $\begin{array}{l}-0.050^{* *} \\
(-3.03)\end{array}$ & $\begin{array}{l}-0.043^{\wedge} \\
(-1.87)\end{array}$ & $\begin{array}{l}0.065^{\star \star} \\
(3.05)\end{array}$ & $\begin{array}{l}-0.062^{\star *} \\
(-3.02)\end{array}$ & $\begin{array}{l}-0.044 \\
(-1.45)\end{array}$ & $\begin{array}{c}0.033 \\
(1.46)\end{array}$ & $\begin{array}{l}-0.026 \\
(-0.92)\end{array}$ & $\begin{array}{l}-0.043 \\
(-1.18)\end{array}$ \\
\hline Local retail investors & $\begin{array}{l}-0.048^{* *} \\
(-2.95)\end{array}$ & $\begin{array}{c}0.034^{\wedge} \\
(1.88)\end{array}$ & $\begin{array}{l}0.087^{\star \star} \\
(3.28)\end{array}$ & $\begin{array}{l}-0.024 \\
(-1.08)\end{array}$ & $\begin{array}{c}0.016 \\
(0.75)\end{array}$ & $\begin{array}{c}0.061^{\wedge} \\
(1.71)\end{array}$ & $\begin{array}{l}-0.081^{* *} \\
(-3.39)\end{array}$ & $\begin{array}{l}0.071 \text { * } \\
(2.32)\end{array}$ & $\begin{array}{l}0.122^{\star \star} \\
(3.06)\end{array}$ \\
\hline
\end{tabular}

Panel B. Coefficient Estimates on Upgrade/Downgrade Dummies in Regression on Standardized Trade Imbalance

\begin{tabular}{|c|c|c|c|c|c|c|}
\hline \multirow[b]{2}{*}{ Investor Type: } & \multicolumn{2}{|c|}{ All Analysts } & \multicolumn{2}{|c|}{ Local Analysts } & \multicolumn{2}{|c|}{ Foreign Analysts } \\
\hline & Upgrade & Downgrade & Upgrade & Downgrade & Upgrade & Downgrade \\
\hline Foreign investors & $\begin{array}{c}0.042^{\wedge} \\
(1.91)\end{array}$ & $\begin{array}{l}-0.070^{\star} \\
(-2.40)\end{array}$ & $\begin{array}{c}0.009 \\
(0.34)\end{array}$ & $\begin{array}{c}0.041 \\
(1.00)\end{array}$ & $\begin{array}{l}0.094^{\star *} \\
(2.61)\end{array}$ & $\begin{array}{l}-0.165^{\star \star} \\
(-4.03)\end{array}$ \\
\hline Local institutions & $\begin{array}{l}0.079^{\star \star} \\
(3.25)\end{array}$ & $\begin{array}{l}-0.074^{*} \\
(-2.11)\end{array}$ & $\begin{array}{l}0.074^{*} \\
(2.33)\end{array}$ & $\begin{array}{c}-0.092^{\wedge} \\
(-1.77)\end{array}$ & $\begin{array}{c}0.088^{*} \\
(2.30)\end{array}$ & $\begin{array}{l}-0.058 \\
(-1.23)\end{array}$ \\
\hline Local retail investors & $\begin{array}{l}-0.058^{*} \\
(-2.29)\end{array}$ & $\begin{array}{l}0.147^{\star \star} \\
(3.78)\end{array}$ & $\begin{array}{l}-0.009 \\
(-0.29)\end{array}$ & $\begin{array}{l}0.119^{*} \\
(2.01)\end{array}$ & $\begin{array}{l}-0.135^{\text {** }} \\
(-3.42)\end{array}$ & $\begin{array}{l}0.172^{\star \star} \\
(3.31)\end{array}$ \\
\hline
\end{tabular}

than foreign sells, foreign investors buy following local sells. While local institutions trade in the right direction in response to sells and buys from both local and foreign analysts, the ratio of their standardized trade imbalance following buys to their standardized trade imbalance following sells for local analysts $(=-1.48)$ is higher in absolute terms relative to the corresponding ratio for foreign analysts $(=$ $-0.77)$. This indicates that local institutions trade as if the information in local analyst buys relative to sells is higher than that in foreign analyst buys relative to sells. ${ }^{17}$

The trade reaction graphs in Figure 1 map out the standardized trade imbalance by investor type, two days before to five days after recommendation announcements from local and foreign analysts. They depict a rich and intuitive pattern in investor behavior. In addition to corroborating the results from Table 8 , the trade reaction graphs suggest that foreign investors may get a sneak peak at the analyst reports (local and foreign) before they are announced. ${ }^{18}$ Neither local

\footnotetext{
${ }^{17}$ One caveat is that in response to upgrades and downgrades, domestic institutions correctly trade as if local upgrades contain less information than local downgrades and as if foreign upgrades contain more information than foreign downgrades.

${ }^{18}$ The standardized trade imbalances of foreign investors are statistically different from zero two days prior to the announcements but statistically positive one day prior to the announcements. Specifically, the $t$-statistic that tests whether the standardized trade imbalance for foreign investors one day prior to an announcement is equal to zero is 2.46 for all analyst buys, 1.76 for local analyst buys, and
} 
institutions nor local retail investors demonstrate a similar uncanny ability to predict analyst announcements. This finding echoes the results of Irvine, Lipson, and Puckett (2006) who show that U.S. institutions receive and act on tips on analyst recommendations up to five days in advance of the announcement date. In addition, the pattern in the standardized trade imbalance of retail investors suggests that they tend to react with a lag of two or three days to local analyst recommendation announcements. This is consistent with the view that while institutions (local and foreign) get timely access to analyst reports in exchange for brokerage business, retail investors must contend with less preferential access to analyst research.

\section{FIGURE 1}

Trade Reaction to Local and Foreign Analysts' Recommendations Grouped by Investor Type

Figure 1 shows the standardized trade imbalance of various investor types in relation to local and foreign analyst recommendations. The sample period is from 1995 to 2003. Analysts are classified as local or foreign according to the location of the head office of their brokerage relative to the stock covered. Standardized trade imbalance is the ratio of buys minus sells divided by total buys and sells after adjusting for firm and year fixed effects and the volatility differences across firms. Day 0 corresponds to the day of the recommendation announcement.
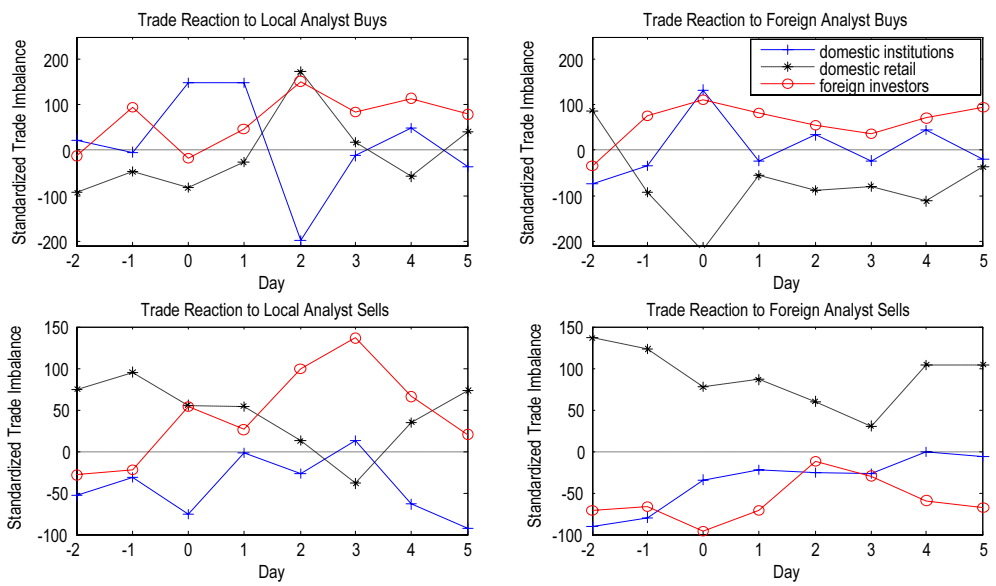

Our trade reaction results also relate to those of Malmendier and Shanthikumar (2006) who analyze the reaction of small and large trades around analyst recommendations. Malmendier and Shanthikumar (2006) find that large traders are better able to recognize the bias in analyst recommendations than small traders. Their results are consistent with our trade reaction results to the extent that the local institutions (i.e., the large traders) exert selling pressure following holds by local analysts while the local retail investors (i.e., the small traders) exert pressure that is statistically indistinguishable from zero following holds by local analysts. The local institutions appear to be aware of the tendency of local analysts to issue holds when sells are warranted, whereas the local retail investors appear to be unaware of this bias.

In summary, the results in this section indicate that while sophisticated foreign investors and local institutions in emerging markets actively follow analyst

1.73 for foreign analyst buys. This is also consistent, however, with foreign investors trading on the same information as that in analyst buy reports on the day before the announcement. 
recommendations, they do not fully internalize the relative optimism of local analysts. They trade, incorrectly, as if foreign analysts are more optimistic than local analysts. It seems that these investors overestimate the pressures facing foreign analysts and underestimate the pressures facing local analysts. ${ }^{19}$ Hence, the ability of sophisticated investors to unravel and correctly assess the investment banking pressures of sell-side analysts, purported by Morgan Stanley, appears suspect.

\section{Discussion}

Many factors may drive the higher levels of optimism among local analysts. Local analysts may face greater pressures to generate brokerage commissions than do foreign analysts. Reputable foreign analysts may seek to protect their stellar reputations by not making biased calls. Foreign analysts may cover firms with greater institutional presence. Because analysts depend on institutions for performance ratings and brokerage commissions, pressures by institutional investors may induce foreign analysts to generate more objective reports (Ljungqvist et al. (2007)). Foreign analysts may shade their recommendations in light of the currency and country risks inherent in emerging country stocks. Local analysts may suffer from familiarity bias. Alternatively, local analysts may be biased because they have prior underwriting relations with local firms. The selection hypothesis (McNichols and O'Brien (1997)) suggests that this bias may stem from IPO firms choosing underwriters with analysts who are predisposed to the firm. Alternatively, the cognitive bias hypothesis (Kahneman and Lovallo (1993)) contends that affiliated analysts are biased because they truly believe that the firms they underwrite are superior to the firms underwritten by their competitors. Finally, local analysts may face greater investment banking pressure ${ }^{20}$ than do foreign analysts. This section carefully explores the possibility that these factors motivate the difference in recommendation optimism between local and foreign analysts.

\section{A. Brokerage Commissions}

If local analysts truly face greater pressures to generate brokerage commissions than do foreign analysts, it may explain why local analysts issue more buy recommendations. However, the difference in the number of buy recommendations issued is small (see Table 2). Moreover, if the pressure to generate commissions motivates the bias difference between local and foreign analysts, then the bias difference should be exacerbated when we limit ourselves to large stocks. By definition, institutions hold more, in dollar terms, large stocks than small stocks. Pressures to generate commissions should be less acute with small stocks. ${ }^{21}$ However, we find that the coefficient on the local analyst dummy for small stocks (see

\footnotetext{
${ }^{19}$ To reconcile these results with those of Table 6 , there must be informed traders at the margin who correctly estimate the pressures facing local and foreign analysts.

${ }^{20}$ Clearly, investment banking pressure can exist net of underwriter affiliation effects. Intuitively, the need to generate future investment banking business, and not just the need to reward past investment banking business, should motivate optimism among sell-side analysts.

${ }^{21}$ This argument implicitly assumes that analysts cater more to institutions than to retail investors. Our trade reaction results in Table 8 indicate that this is a reasonable assumption. Unlike institutional
} 
column four in Panel A of Table 5) is still comparable to that for the full sample and is highly statistically significant. Hence, it is unlikely that the pressure to generate brokerage commissions lies at the root of our results.

\section{B. Analyst Reputation Concerns}

If foreign analysts are more reputable than local analysts, then foreign analysts may be more inclined to issue objective recommendations to protect their reputations. Table 1 indicates that foreign analysts belong to larger brokerages employing more analysts. Relative to local analysts, these foreign analysts are likely to be better paid and have better reputations. However, if the reputation concerns story holds, then reputable analysts should be more objective than other analysts. To test this directly, we augment the equation (3) and equation (4) regressions of Table 3 with a dummy that equals one if an analyst belongs to an Institutional Investor magazine All-Asia team ${ }^{22}$ in the previous election year, and equals zero otherwise. We find that analysts from All-Asia teams are more optimistic than other analysts. These results are statistically significant at the $1 \%$ level ( $t$-statistic $=2.63$ in the augmented equation (4) regression), and run counter to the view that the higher reputation results in lower recommendation optimism among analysts. In fact, when we breakdown the All-Asia team dummy into a dummy for the first-place All-Asia team, a dummy for the second-place All-Asia team, etc., we find that analysts in the first-place All-Asia team are significantly more optimistic than other analysts $(t$-statistic $=5.49$ in the augmented equation (4) regression). Moreover, the coefficient estimates fall as we move from the first-place to the fourth-place team dummy (All-Asia analysts are placed into four teams) strongly suggesting that having a better reputation does not necessarily result in lower optimism among analysts.

\section{Institutional Presence}

Greater institutional presence among stocks recommended by foreign analysts may also account for the lower levels of optimism among foreign analysts (Ljungqvist et al. (2007)). This view necessarily implies that the difference in bias falls when we constrain the sample to MSCI index stocks, which are widely held by institutions and where variation in institutional presence is less than across the full sample of firms. By reestimating the regressions in equations (3) and (4) on the sample of MSCI firms, we find that the difference in optimism levels between local and foreign analysts is actually larger relative to that for the full sample of firms. The coefficients on the local analyst dummy for the MSCI sample of firms are $0.120(t$-statistic $=13.86)$ and $0.117(t$-statistic $=11.27)$ for the regressions in equations (3) and (4), respectively (see Table 5). Those for the full sample are 0.116 and 0.104 , respectively (see Table 3 ). The strength of the local analyst

investors, retail investors seem to react with a significant lag to analyst recommendation announcements.

${ }^{22}$ To select members for the All-Asia teams (which are analogous to the All-America teams), Institutional Investor sends a questionnaire to directors of research and heads of investment at approximately 400 institutions and investment firms that are major investors in the Asia ex-Japan region. The rankings are published in May every year. 
dummy coefficients in the MSCI index stock sample indicates that institutional presence does not account for the difference in optimism levels between local and foreign analysts.

\section{Country and Currency Risk}

Institutional presence aside, foreign analysts, who cater primarily to sophisticated foreign institutions, may shade their recommendations of emerging market stocks in light of the country and currency risks inherent in emerging markets. To test this hypothesis, we augment the equation (4) regression in Table 3 with three independent variables: currency risk, country risk, and the interaction of country risk with the local analyst dummy. For a recommendation issued by an analyst headquartered in country $x$ and on a stock in country $y$, we take as currency risk the standard deviation of daily returns of currency $y$ relative to base currency $x$ over the past year. By definition, the currency risk for local analyst recommendations is zero since $x$ equals $y$ in those cases. We use the Euromoney's annual estimate of country risk as our country risk variable. ${ }^{23}$

Not surprisingly, we find that the coefficients on currency risk and country risk are both negative and statistically different from zero, reflecting the dampening effect that risk has on recommendation optimism levels. However, the interaction variable between the country risk and the local analyst dummy variable is mildly negative (but statistically indistinguishable from zero) as well. It appears that country risk affects local analyst recommendations more than it affects foreign analyst recommendations. Consequently, the coefficient estimate on the local analyst dummy is virtually identical (coefficient estimate $=0.103$ ) with the augmented equation (4) regression and remains statistically different from zero at the $1 \%$ level $(t$-statistic $=8.20)$. One possible reason for this is that local analysts, unlike foreign analysts, are affected by prevailing local sentiment, which is negatively correlated with country risk.

\section{E. Familiarity Bias}

Moreover, the optimism of local analysts may be driven by familiarity bias, which has been linked to the traditional home bias literature (see, for example, Bailey, Kumar, and Ng (2006)). The familiarity bias story suggests that local analysts may develop a stronger preference for local stocks because they are more in tune with local companies than are foreign analysts. This view also implies that the local analyst optimism should fall once we control for the number of stocks covered. Further, any familiarity bias-induced optimism differences should be attenuated when we compare local analysts to foreign analysts who reside locally. However, in Table 3, we find that controlling for the number of firms an analyst covers barely affects the coefficient estimate on the local analyst dummy. Also, in Panel B of Table 5 we find that foreign analysts whose brokerages have a local presence (and, hence, are more likely to reside locally) are only somewhat less

\footnotetext{
${ }^{23}$ Euromoney gives a higher score (ranging from 0 to 100 ) to a less risky country. We transform the score and use (100-original Euromoney score)/10 so that the score is positively correlated with the level of risk.
} 
pessimistic (relative to local analysts) than foreign analysts whose brokerages do not have a local presence.

\section{F. Selection and Cognitive Biases}

Another explanation for the greater optimism of local analysts could be that there are more local than foreign affiliated analysts and that affiliated analysts suffer from selection or cognitive biases. That is, either firms select underwriters based in part on how favorable the underwriter's analysts are about the firm (McNichols and O'Brien (1997)), or analysts believe that any firm underwritten by their brokerage must be superior to firms underwritten by competing brokerages (Kahneman and Lovallo (1993)). If this holds true, then the optimism differences between local and foreign analysts should disappear once we control for analyst affiliation status. To this end, we reestimate the equation (3) and equation (4) regressions augmented with a dummy for past underwriter affiliation and a dummy for future underwriter affiliation. Our analysis includes only firms for which we have underwriter information from 1990 to 2004. As a result, the number of firm recommendation observations falls by about $47 \%$ relative to that in Table 3 . We consider several variants of the affiliation dummies including one-, two-, fiveyear, and infinite year affiliation dummies. The one-year past affiliation dummy takes a value of one if the analyst belongs to the lead or co-lead underwriter for the firm's IPO or SEO not more than a year ago. It takes a value of zero otherwise. The other past affiliation dummies and the future affiliation dummies are defined analogously.

The pattern in past and future affiliation dummy coefficients reported in Table 9 is intriguing. Over all horizons, the coefficient for the past affiliation dummy is positive. With the infinite look-back period, the past affiliation dummy is statistically different from zero at the 5\% level for both the equation (3) and equation (4) regressions. At the same time, the future affiliation dummy is statistically positive over all of the look-ahead horizons. With the infinite look-ahead horizon, the coefficient estimate on the future affiliation dummy is about one and a half times that of the corresponding past affiliation dummy. Nonetheless, despite the explanatory power of the affiliation dummies and the $47 \%$ reduction in sample size, the local analyst dummy coefficient is still statistically positive at the $1 \%$ level for all regression specifications. A comparison of the coefficients on the local analyst dummy for the most comprehensive regression specification (equation (4)) in Table 3 and in Table 9 reveals that the infinite horizon past and future affiliation effects only account for less than $5 \%$ of the optimism differences between local and foreign analysts. Clearly, one cannot explain the bulk of the optimism differences with underwriting-induced selection and cognitive bias.

\section{G. Investment Banking Pressures}

The evidence presented thus far suggests that the difference in recommendation optimism between local and foreign analysts is not mainly driven by brokerage commissions, reputation concerns, institutional presence, country and currency risk, familiarity bias, and underwriting-induced selection and cognitive 
TABLE 9

Regressions on Analyst Recommendation Optimism Controlling for Underwriter Affiliation

Pooled OLS regressions are estimated from January 1994 to December 2003 across all analyst recommendation/firm observations in the sample at that time. The dependent variable is the analyst recommendation minus this month's median recommendation. In the augmented equation (3) regressions, the independent variables are the local analyst dummy, the past affiliation dummy, the future affiliation dummy, the log of firm size, the number of firms covered by the analyst, the number of analysts covering the firm, the experience level in years of the analyst, and the full set of country and year dummies. In the augmented equation (4) regressions, the number of analysts employed by the brokerage is also included among the regressors. Observations with consensus generated with less than three observations are excluded from the analysis. Firms without IPO/SEO lead underwriter information are also excluded from the analysis. The analysis includes both domestic and international issues. The recommendation variable takes the following values: $3=$ buy, $2=$ hold, and $1=$ sell. The past affiliation dummy $(\leq 1$ year post-IPO/SEO) takes a value of 1 if the analyst belongs to a brokerage that was the lead or joint lead manager for the firm's IPO or SEO not more than a year ago. It takes a value of 0 otherwise. The other affiliation dummies are defined analogously. The future affiliation dummy ( $\leq 1$ year pre-IPO/SEO) takes a value of 1 if the analyst belongs to a brokerage that will be the lead or joint lead manager for the firm's IPO or SEO not more than a year in the future. It takes a value of 0 otherwise. The other future affiliation dummies are defined analogously. Only the coefficients on the local analyst dummy and the affiliation dummies are reported for brevity. The number of observations for each regression is 64,537 . The $t$-statistics derived using White $(1980)$ standard errors are in parentheses. " $=$ significant at the $10 \%$ level, ${ }^{*}=$ significant at the $5 \%$ level, and ${ }^{* *}=$ significant at the $1 \%$ level.

Augmented with Affiliation Dummies

\begin{tabular}{|c|c|c|c|c|c|c|c|c|}
\hline \multirow{2}{*}{ Independent Variable } & \\
\hline & Eq. (3) & Eq. (4) & Eq. (3) & Eq. (4) & Eq. (3) & Eq. (4) & Eq. (3) & Eq. (4) \\
\hline Local analyst dummy & $\begin{array}{l}0.117^{* *} \\
(14.07)\end{array}$ & $\begin{array}{l}0.108^{\star *} \\
(10.82)\end{array}$ & $\begin{array}{l}0.118^{\star \star} \\
(14.11)\end{array}$ & $\begin{array}{l}0.109^{\star \star} \\
(10.84)\end{array}$ & $\begin{array}{l}0.117^{\star *} \\
(13.95)\end{array}$ & $\begin{array}{l}0.106^{\star *} \\
(10.59)\end{array}$ & $\begin{array}{l}0.115^{\star *} \\
(13.79)\end{array}$ & $\begin{array}{l}0.105^{\star \star} \\
(10.39)\end{array}$ \\
\hline $\begin{array}{l}\text { Past affiliation dummy } \\
\text { ( } \leq 1 \text {-year post-IPO/SEO) }\end{array}$ & $\begin{array}{l}0.057^{\wedge} \\
(1.65)\end{array}$ & $\begin{array}{l}0.060^{\wedge} \\
(1.72)\end{array}$ & & & & & & \\
\hline $\begin{array}{l}\text { Past affiliation dummy } \\
(\leq 2 \text {-years post-IPO/SEO) }\end{array}$ & & & $\begin{array}{c}0.008 \\
(0.31)\end{array}$ & $\begin{array}{c}0.010 \\
(0.40)\end{array}$ & & & & \\
\hline $\begin{array}{l}\text { Past affiliation dummy } \\
(\leq 5 \text {-years post-IPO/SEO) }\end{array}$ & & & & & $\begin{array}{l}0.036^{\wedge} \\
(1.91)\end{array}$ & $\begin{array}{l}0.039^{*} \\
(2.04)\end{array}$ & & \\
\hline $\begin{array}{l}\text { Past affiliation dummy } \\
\qquad(\leq \infty \text { years post-IPO/SEO) }\end{array}$ & & & & & & & $\begin{array}{l}0.050^{\star \star} \\
(3.05)\end{array}$ & $\begin{array}{l}0.053^{\star \star} \\
(3.21)\end{array}$ \\
\hline $\begin{array}{l}\text { Future affiliation dummy } \\
(\leq 1 \text {-year pre-IPO/SEO) }\end{array}$ & $\begin{array}{l}0.120^{* *} \\
(2.80)\end{array}$ & $\begin{array}{l}0.123^{\star *} \\
(2.86)\end{array}$ & & & & & & \\
\hline $\begin{array}{l}\text { Future affiliation dummy } \\
\text { ( } \leq 2 \text {-years pre-IPO/SEO) }\end{array}$ & & & $\begin{array}{l}0.102^{\star \star} \\
(3.11)\end{array}$ & $\begin{array}{l}0.105^{\star *} \\
(3.19)\end{array}$ & & & & \\
\hline $\begin{array}{l}\text { Future affiliation dummy } \\
(\leq 5 \text {-years pre-IPO/SEO) }\end{array}$ & & & & & $\begin{array}{l}0.088^{\star \star} \\
(3.41)\end{array}$ & $\begin{array}{l}0.091^{\star \star} \\
(3.53)\end{array}$ & & \\
\hline $\begin{array}{l}\text { Future affiliation dummy } \\
\qquad(\leq \infty \text { years pre-IPO/SEO })\end{array}$ & & & & & & & $\begin{array}{l}0.075^{\star \star} \\
(3.14)\end{array}$ & $\begin{array}{l}0.078^{\star \star} \\
(3.27)\end{array}$ \\
\hline
\end{tabular}

bias. It remains to test the link between investment banking pressures (sans underwriter affiliation effects) and local analyst recommendation optimism.

In this effort, we estimate the equation (4) regressions augmented with two investment banking proxies: the number of equity issues within the firm's country and the proportion of equity issues underwritten by brokerages in the analyst's brokerage country. ${ }^{24}$ We hypothesize that when issue volume is higher and hence market-wide investment banking pressures are stronger, local analysts are even more optimistic, relative to their foreign counterparts, than when issue volume is low. Hence, the first proxy enters as an interaction variable in the regression. The second proxy enters directly into the regression as it captures investment banking pressures specific to the analyst's brokerage country. We also include past and future affiliation dummies (with an infinite look-back/-ahead period) among the

\footnotetext{
${ }^{24}$ The proportion of equity issues is based on the ratio of the number of equity issues underwritten by brokerages in the analyst's country to the total number of equity issues. In results available from the authors, we perform the analogous, augmented equation (3) regressions, and use investment banking proxies based on the value of equity issues. We obtain qualitatively similar results with these alternative specifications.
} 
regressors to abstract from any affiliation effects. We consider investment banking proxies lagged one year, in the current year, and one year ahead to accommodate any lead/lag effects.

The coefficient estimates reported in Table 10 reveal a strong link between the investment banking proxies and differences between local and foreign analyst recommendation optimism. Relative to the baseline regression results in the far right column of Table 9, the results in the far right column of Table 10 indicate that variation in the investment banking proxies explains up to $87 \%$ of the coefficient estimate on the local analyst dummy. Indeed, relative recommendation optimism among local analysts appears to be correlated with the number and proportion (by brokerage country) of issues underwritten in the next year. The coefficient estimates in the fifth column of Table 10 suggest that the number and proportion of issues in the next year alone can explain $70 \%$ of the optimism differences between local and foreign analysts. Insofar as optimistic analyst reports parlay into future business for underwriters, this suggests that analysts correctly anticipate changes in the issue volume and proportion, and adjust their recommendation optimism accordingly. ${ }^{25}$ More importantly, the positive and statistically significant coefficients on the investment banking proxies one year ahead suggest that local analysts increase their recommendation optimism more than foreign analysts in response to anticipated increases in the issue volume, and that analysts based in countries that capture a higher proportion of underwriting in the market are more optimistic than others. In fact, the results in Table 10 indicate that the local analyst dummy in Table 3 only matters to the extent that it captures the higher levels of investment banking business directed to local brokerages (see Table A1). This provides clear and direct evidence relating investment banking pressures to the delta in optimism between local and foreign analysts.

\section{Conclusion}

This study documents a unique and novel form of home bias. We show that local analyst recommendations in emerging market stocks are more optimistic than foreign analyst recommendations. This pattern of optimism is pervasive across countries, time periods, small stocks, large stocks, value stocks, growth stocks, index stocks, and non-index stocks, and persists even after controlling for analyst affiliation.

It also has important implications for returns. On one hand, upgrades and buy recommendations by foreign analysts convey more positive information than upgrades and buy recommendations by local analysts. On the other hand, downgrades and sell recommendations by local analysts convey more negative information than downgrades and sell recommendations by foreign analysts. Yet, neither sophisticated foreign investors nor local institutions fully account for the differences in optimism between local and foreign analysts. In particular, foreign investors trade, incorrectly, as if foreign analysts' sells are more informative than

\footnotetext{
${ }^{25}$ Of course the causality could run the other way. That is, optimistic analyst reports parlay into greater investment banking deal flow in the future. However the fact that we already include future underwriter affiliation as one of the controls in the Table 10 regressions suggests that this is unlikely to be the case.
} 
TABLE 10

Sensitivity of Recommendation Optimism to International Investment Banking Proxies

Pooled OLS regressions are estimated from January 1994 to December 2003 across all analyst recommendation/firm observations in the sample at that time. The dependent variable is analyst recommendation minus this month's median recommendation. The independent variables are the local analyst dummy, the past affiliation dummy, the future affiliation dummy, the local analyst dummy interacted with the number of issues in the firm's country in a year (in thousands), the proportion of equity issues underwritten by brokerages headquartered in the same country as the analyst's brokerage, the log of firm size, the number of firms covered by the analyst, the number of analysts covering the firm, the experience level in years of the analyst, the number of analysts employed by the brokerage, and the full set of country and year dummies. Observations with consensus generated with less than three observations are excluded from the analysis. Firms without IPO/SEO lead underwriter information are also excluded from the analysis. The analysis includes both domestic and international issues. The recommendation variable takes the following values: $3=$ buy, $2=$ hold, and $1=$ sell. The past affiliation dummy takes a value of 1 if the analyst belongs to a brokerage that was the lead or joint lead manager for the firm's IPO or SEO. It takes a value of 0 otherwise. The future affiliation dummy takes a value of 1 if the analyst belongs to a brokerage that will be the lead or joint lead manager for the firm's IPO or SEO. It takes a value of 0 otherwise. Only the coefficients on the local analyst dummy, the affiliation dummies, and the investment banking variables are reported for brevity. The number of observations for each regression is 64,537 . The $t$-statistics derived using White (1980) standard errors are in parentheses. ${ }^{\wedge}=$ significant at the $10 \%$ level, ${ }^{*}=$ significant at the $5 \%$ level, and ${ }^{* *}=$ significant at the $1 \%$ level.

\begin{tabular}{|c|c|c|c|c|c|c|c|c|}
\hline Independent Variable & & & $\begin{array}{r}\text { Equation (4) } \\
\text { and }\end{array}$ & $\begin{array}{l}\text { Augmente } \\
\text { Investmen }\end{array}$ & $\begin{array}{l}d \text { with Affil } \\
\text { Banking }\end{array}$ & $\begin{array}{l}\text { ation Dummie } \\
\text { roxies }\end{array}$ & & \\
\hline Local analyst dummy & $\begin{array}{l}0.095^{\star *} \\
(6.26)\end{array}$ & $\begin{array}{l}0.059^{\star \star} \\
(3.99)\end{array}$ & $\begin{array}{l}0.071^{\star *} \\
(4.15)\end{array}$ & $\begin{array}{l}0.056^{\star \star} \\
(3.12)\end{array}$ & $\begin{array}{c}0.031^{\wedge} \\
(1.75)\end{array}$ & $\begin{array}{l}0.080^{\star \star} \\
(4.64)\end{array}$ & $\begin{array}{c}0.027 \\
(1.57)\end{array}$ & $\begin{array}{c}0.014 \\
(0.64)\end{array}$ \\
\hline $\begin{array}{l}\text { Past affiliation dummy } \\
(\leq \infty \text { years } \\
\text { post-IPO/SEO })\end{array}$ & $\begin{array}{l}0.053^{\star \star} \\
(3.19)\end{array}$ & $\begin{array}{l}0.052^{\star \star} \\
(3.12)\end{array}$ & $\begin{array}{l}0.050^{\star \star} \\
(3.02)\end{array}$ & $\begin{array}{l}0.051^{\star \star} \\
(3.11)\end{array}$ & $\begin{array}{l}0.050^{\star *} \\
(3.03)\end{array}$ & $\begin{array}{l}0.052^{\star \star} \\
(3.13)\end{array}$ & $\begin{array}{l}0.050^{\star *} \\
(3.00)\end{array}$ & $\begin{array}{l}0.049^{\star \star} \\
(2.97)\end{array}$ \\
\hline $\begin{array}{l}\text { Future affiliation dummy } \\
\qquad \leq \infty \text { years } \\
\text { pre-IPO/SEO })\end{array}$ & $\begin{array}{l}0.078^{\star *} \\
(3.27)\end{array}$ & $\begin{array}{l}0.075^{\star \star} \\
(3.13)\end{array}$ & $\begin{array}{l}0.076^{\star *} \\
(3.17)\end{array}$ & $\begin{array}{l}0.075^{\star \star} \\
(3.13)\end{array}$ & $\begin{array}{l}0.073^{* *} \\
(3.06)\end{array}$ & $\begin{array}{l}0.078^{\star \star} \\
(3.24)\end{array}$ & $\begin{array}{l}0.072^{* *} \\
(3.02)\end{array}$ & $\begin{array}{l}0.072^{\star \star} \\
(3.01)\end{array}$ \\
\hline $\begin{array}{l}\text { Local analyst dummy } * \\
\text { total number of issues } \\
\text { in firm country }(Y-1)\end{array}$ & & & $\begin{array}{l}-0.016 \\
(-1.17)\end{array}$ & & & $\begin{array}{l}-0.009 \\
(-0.51)\end{array}$ & & $\begin{array}{c}0.003 \\
(0.18)\end{array}$ \\
\hline $\begin{array}{l}\text { Local analyst dummy } * \\
\text { total number of issues } \\
\text { in firm country }(Y)\end{array}$ & $\begin{array}{c}0.015 \\
(0.94)\end{array}$ & & & $\begin{array}{c}0.007 \\
(0.42)\end{array}$ & & $\begin{array}{l}-0.010 \\
(-0.39)\end{array}$ & & $\begin{array}{l}-0.029 \\
(-1.12)\end{array}$ \\
\hline $\begin{array}{l}\text { Local analyst dummy } * \\
\text { total number of issues } \\
\text { in firm country }(Y+1)\end{array}$ & & & & & $\begin{array}{l}0.036^{*} \\
(2.34)\end{array}$ & $\begin{array}{l}0.052^{\star \star} \\
(2.62)\end{array}$ & & $\begin{array}{l}0.047^{*} \\
(2.36)\end{array}$ \\
\hline $\begin{array}{l}\text { Proportion of issues } \\
\text { underwritten } \\
\text { by brokerages } \\
\text { in analyst country }(Y-1)\end{array}$ & & & $\begin{array}{l}0.077^{\text {** }} \\
(3.95)\end{array}$ & & & & $\begin{array}{c}0.028 \\
(1.28)\end{array}$ & $\begin{array}{c}0.020 \\
(0.90)\end{array}$ \\
\hline $\begin{array}{l}\text { Proportion of issues } \\
\text { underwritten } \\
\text { by brokerages } \\
\text { in analyst country }(Y)\end{array}$ & & $\begin{array}{l}0.082^{\star \star} \\
(4.20)\end{array}$ & & $\begin{array}{l}0.081^{\star \star} \\
(4.10)\end{array}$ & & & $\begin{array}{l}0.046^{*} \\
(2.06)\end{array}$ & $\begin{array}{l}0.048^{*} \\
(2.15)\end{array}$ \\
\hline $\begin{array}{l}\text { Proportion of issues } \\
\text { underwritten } \\
\text { by brokerages } \\
\text { in analyst country }(Y+1)\end{array}$ & & & & & $\begin{array}{l}0.092^{* *} \\
(4.70)\end{array}$ & & $\begin{array}{l}0.070 \text { ** } \\
(3.20)\end{array}$ & $\begin{array}{l}0.069^{\star *} \\
(3.00)\end{array}$ \\
\hline
\end{tabular}

their buys while local institutions trade, incorrectly, as if local analysts' buys are more informative than their sells.

The fact that emerging market stocks are typically underwritten by local brokerages suggests that differences in investment banking pressure between local and foreign underwriters may be at the root of the differences in recommendation optimism. We consider various competing explanations including brokerage commission pressures, analyst reputation concerns, institutional presence, currency and country risk, familiarity bias, and underwriting-induced selection and cognitive biases, but find no evidence to suggest that these explanations account for the bulk of the optimism differences. In contrast, country-specific investment banking proxies completely account for those optimism differences. 
The results suggest several avenues for future work. In studies on the classic home bias, a better understanding of how local investors react to optimistic local analyst recommendations may shed light on why local investors gravitate toward local stocks. In studies on international investors, incorporating differences in recommendation optimism between local and foreign analysts may help account for differences in trading profits and apparent informational asymmetries between local and foreign investors.

TABLE A1

Equity Issues in Emerging Markets

Table A1 shows the number of domestic equity issues for the eight emerging countries that we study. The sample period is from January 1994 to December 2003. Lead underwriters are classified into local and foreign based on the locations of their head offices. Only equity issues with underwriter information are included in the sample. Equity issues are classified as Local Lead Underwriter issues if the sole managing underwriter is local or if there are no foreign underwriters among the joint managing underwriters. All other issues are classified as Foreign Lead Underwriter issues.

\begin{tabular}{|c|c|c|c|c|c|c|}
\hline \multirow[b]{2}{*}{ Country } & \multicolumn{2}{|c|}{ Total Equity Issue Market } & \multicolumn{2}{|c|}{ Local Lead Underwriters } & \multicolumn{2}{|c|}{ Foreign Lead Underwriters } \\
\hline & No. of Issues & Cap (U.S.\$bn) & $\%$ (No.) & \% (Market Cap) & $\%$ (No.) & \% (Market Cap) \\
\hline India & 1,166 & 3.43 & 97.43 & 90.82 & 2.57 & 9.18 \\
\hline Indonesia & 212 & 3.95 & 78.77 & 69.67 & 21.23 & 30.34 \\
\hline Korea & 881 & 51.23 & 96.37 & 95.61 & 3.29 & 4.29 \\
\hline Malaysia & 946 & 14.49 & 97.67 & 96.65 & 2.22 & 3.31 \\
\hline Philippines & 122 & 2.86 & 87.71 & 86.18 & 12.30 & 13.82 \\
\hline Singapore & 564 & 10.82 & 80.85 & 72.82 & 18.97 & 26.97 \\
\hline Taiwan & 501 & 18.69 & 98.80 & 99.78 & 1.20 & 0.22 \\
\hline Thailand & 136 & 4.75 & 94.85 & 95.24 & 5.15 & 4.76 \\
\hline
\end{tabular}

\section{References}

Bacmann, J. F., and G. Bolliger. "Who Are The Best? Local Versus Foreign Analysts on the Latin American Stock Markets.” Working Paper, University of Neuchatel (2006).

Bae, K. H.; R. M. Stulz; and H. Tan. "Do Local Analysts Know More? A Cross-Country Study of the Performance of Local Analysts and Foreign Analysts." Working Paper, Ohio State University (2006).

Bailey, W.; A. Kumar; and D. Ng. "Venturing Abroad: Foreign Investments of U.S. Individual Investors." Working Paper, Cornell University (2006).

Barber, B.; Y. T. Lee; Y. J. Liu; and T. Odean. "Who Loses from Trade? Evidence from Taiwan." Working Paper, University of California at Berkeley (2006).

Barber, B.; R. Lehavy; M. McNichols; and B. Trueman. "Can Investors Profit from the Prophets? Security Analyst Recommendations and Stock Returns.” Journal of Finance, 56 (2001), 531-563.

Barber, B.; R. Lehavy; M. McNichols; and B. Trueman. "Buys, Holds, and Sells: The Distribution of Investment Banks' Stock Ratings and the Implications for the Profitability of Analysts' Recommendations." Journal of Accounting and Economics, 41 (2006), 87-117.

Barber, B.; R. Lehavy; and B. Trueman. "Comparing the Stock Recommendation Performance of Investment Banks and Independent Research Firms.” Journal of Financial Economics, 85 (2007), 490-517.

Carhart, M. "On Persistence in Mutual Fund Performance.” Journal of Finance, 52 (1997), 57-82.

Chang, C. "Information Footholds: Expatriate Analysts in an Emerging Market." Working Paper, University of California at Berkeley (2006).

Choe, H.; B. C. Kho; and R. M. Stulz. "Do Domestic Investors Have an Edge? The Trading Experience of Foreign Investors in Korea." Review of Financial Studies, 18 (2005), 795-829.

Cooper, I., and E. Kaplanis. "Home Bias in Equity Portfolios, Inflation Hedging, and International Capital Market Equilibrium.” Review of Financial Studies, 7 (1994), 45-60.

Dvorak, T. "Do Domestic Investors have an Information Advantage? Evidence from Indonesia." Journal of Finance, 60 (2005), 817-839.

Fama, E., and K. French. "Common Risk Factors in the Returns on Stocks and Bonds." Journal of Financial Economics, 33 (1993), 3-56. 
Fama, E., and K. French. "Value Versus Growth: The International Evidence." Journal of Finance, 53 (1998), 1975-1999.

French, K., and J. Poterba. "Investor Diversification and International Equity Markets." American Economic Review, 81 (1991), 222-226.

Froot, K.; P. G. J. O'Connell; and M. Seasholes. "The Portfolio Flows of International Investors." Journal of Financial Economics, 59 (2001), 151-193.

Grinblatt, M., and M. Keloharju. "The Investment Behavior and Performance of Various Investor Types: A Study of Finland's Unique Data Set." Journal of Financial Economics, 55 (2000), 43-67.

Hau, H. "Location Matters: An Examination of Trading Profits." Journal of Finance, 56 (2001), 1959-1983.

Irvine, P.; M. Lipson; and A. Puckett. "Tipping.” Review of Financial Studies, 20 (2006), 741-768.

Jackson, A. R. "Trade Generation, Reputation, and Sell-Side Analysts." Journal of Finance, 60 (2005), 673-717.

Jegadeesh, N., and S. Titman. "Returns to Buying Winners and Selling Losers: Implications for Stock Market Efficiency." Journal of Finance, 48 (1993), 65-91.

Kahneman, D., and D. Lovallo. "Timid Choices and Bold Forecasts: A Cognitive Perspective on Risk Taking." Management Science, 39 (1993), 17-31.

Lin, H. W., and M. F. McNichols. "Underwriting Relationships, Analysts' Earnings Forecasts and Investment Recommendations." Journal of Accounting and Economics, 25 (1998), 101-127.

Ljungqvist, A.; F. Marston; L. T. Starks; K. D. Wei; and H. Yan. "Conflicts of Interest in Sell-Side Research and the Moderating Role of Institutional Investors." Journal of Financial Economics, 85 (2007), 420-456.

Loughran, T., and J. Ritter. "Uniformly Least Powerful Tests of Market Efficiency." Journal of Financial Economics, 55 (2000), 361-389.

Malloy, C. J. "The Geography of Equity Analysis.” Journal of Finance, 60 (2005), 719-755.

Malmendier, U., and D. Shanthikumar. “Are Investors Naïve about Incentives?” Working Paper No. 10812, NBER (2006).

McNichols, M., and P. O'Brien. "Self-Selection and Analyst Coverage." Journal of Accounting Research, 35 (1997), 167-199.

Michaely, R., and K. L. Womack. "Conflict of Interest and the Credibility of Underwriter Analyst Recommendations.” Review of Financial Studies, 12 (1999), 653-686.

Michaely, R., and K. L. Womack. "Brokerage Recommendations, Stylized Characteristics, Market Responses, and Biases.” In Advances in Behavioral Finance, Vol. II, R. Thaler, ed. Princeton, NJ: Princeton University Press (2005).

Mitchell, M., and E. Stafford. "Managerial Decisions and Long-Term Stock Price Performance." Journal of Business, 73 (2000), 287-329.

Orpurt, S. "Local Analyst Earnings Forecast Advantage in Europe." Working Paper, University of Chicago (2006).

Richards, A. "Big Fish in Small Ponds: The Trading Behavior and Price Impact of Foreign Investors in Asian Emerging Markets." Journal of Financial and Quantitative Analysis, 40 (2005), 1-27.

Seasholes, M. "Reexamining Information Asymmetries in Emerging Markets." Working Paper, University of California at Berkeley (2006).

Stickel, S. E. "Reputation and Performance among Security Analysts." Journal of Finance, 47 (1992), 1811-1836.

Tesar, L., and I. Werner. "Home Bias and High Turnover." Journal of International Money and Finance, 14 (1995), 467-492.

White, H. "A Heteroskedasticity-Consistent Covariance Matrix Estimator and a Direct Test for Heteroskedasticity." Econometrica, 48 (1980), 817-838.

Womack, K. L. “Do Brokerage Analysts' Recommendations Have Investment Value?” Journal of Finance, 51 (1996), 137-167. 